\title{
Numerical simulations of significant orographic precipitation in Madeira island
}

\author{
Flavio Tiago Couto \\ Instituto de Ciências da Terra - Polo de Évora, Departamento de Física, Instituto de \\ Investigação e Formação Avançada - IIFA, Universidade de Évora. \\ Rua Romão Ramalho, 59, 7000-671, Évora, Portugal. \\ (couto.ft@gmail.com) \\ Véronique Ducrocq \\ CNRM-GAME, UMR3589, Météo-France \& CNRS, Toulouse, France. \\ (veronique.ducrocq@meteo.fr)
}

\begin{abstract}
Rui Salgado
Instituto de Ciências da Terra - Polo de Évora, Departamento de Física, Escola de Ciências e Tecnologia, Universidade de Évora, Évora, Portugal. (rsal@uevora.pt)
\end{abstract}

\begin{abstract}
Maria João Costa
Instituto de Ciências da Terra - Polo de Évora, Departamento de Física, Escola de Ciências e Tecnologia, Universidade de Évora, Évora, Portugal. (mjcosta@uevora.pt)
\end{abstract}




\section{Abstract}

High-resolution simulations of high precipitation events with the MESO-NH model are presented, and also used to verify that increasing horizontal resolution in zones of complex orography, such as in Madeira island, improve the simulation of the spatial distribution and total precipitation. The simulations succeeded in reproducing the general structure of the cloudy systems over the ocean in the four periods considered of significant accumulated precipitation. The accumulated precipitation over the Madeira was better represented with the $0.5 \mathrm{~km}$ horizontal resolution and occurred under four distinct synoptic situations. Different spatial patterns of the rainfall distribution over the Madeira have been identified.

Key-words: MESO-NH model, orographic precipitation, Madeira island. 


\section{Introduction}

Heavy precipitation events are one of the major factors inducing floods, which leads to the constant improvement in numerical models and measurement techniques, also reported from several studies worldwide. Accurately representing precipitation systems in atmospheric models is still however challenging, and better forecasts are mandatory to issue early warnings mainly for urban areas. The general environments causing heavy precipitation are well documented for many regions around the world (e.g. Lin et al., 2001), however, the increase of the knowledge about these heavy events on specific regions is needed, for example, over small mountainous and island regions.

The impact of the orography in the formation or enhancement of the precipitation over mountainous islands have been found dependent of the geographic aspects of the island and synoptic conditions associated to each precipitating event (e.g. Wang et al., 2014a, Smith et al., 2012). For example, Wang et al. (2014b), studying two heavy precipitation events over Taiwan showed that the synoptic circulation was dominant over the diurnal effects, and the steep topography of Taiwan was essential to increase the rainfall amount over and near Taiwan. On the other hand, heavy precipitation events may also be induced by several orographic effects. Chen et al. (2010, 2011) identified that orographic lifting and convergence at low-levels caused by the flow deflection due the local orography was related to other precipitation events over Taiwan. In Jeju island, for example, the orographic blocking inducing convergence zones or the intensification of convective cells in the lee side of the elliptical island were some mechanisms favouring heavy precipitation (Lee et al., 2010, 2014).

More attention has been dedicated to the study of precipitation over the Madeira island, a mountainous Portuguese island located in the mid-latitudes $\left(32^{\circ} 75^{\prime} \mathrm{N}\right.$ and $17^{\circ} \mathrm{W}$ ), after the disaster on February 20, 2010 (e.g., Luna et al., 2011; Levizzani et al., 2013). It was the most remarkable event in terms of heavy precipitation observed in Madeira, with high impact at the surface. The study of the winter 2009/2010 by Couto et al. (2012) highlighted the role of an atmospheric river in six out of the seven cases of heavy precipitation over the island, providing significant amount of water vapour from the tropics for the triggering or enhancement of precipitation by the island terrain. Couto et al. (2015) further examined the characteristics of the synoptic environment by carrying out a 10-year analysis of precipitation over the island and satellite water vapour fields over the Atlantic Ocean during the winter periods. They found that atmospheric 
rivers when transporting large amounts of precipitable water, are well correlated with heavy precipitation occurrence over the island. However, there are many other heavy precipitation events over the island that are not favoured by atmospheric rivers, but extra-tropical weather systems. In order to further study heavy precipitation over Madeira associated with extra-tropical weather systems, the same approach as in Couto et al. (2012) is followed by simulating all the heavy precipitation events of autumn 2012, the second wettest season in the 10-year period studied by Couto et al. (2015).

The first aim of this paper is to present these high-resolution simulations and their performance. Contrary to Couto et al. (2012), the convection-permitting simulations are performed in the present study over large model domains (Figure 1) in order not only to describe at high-resolution convection and precipitation enhancement over the Madeira island but also the associated larger-scale cloudy weather systems over the surrounding ocean region.

The Madeira island is a small island (58 km x $23 \mathrm{~km})$, characterized by an eastwest mountain chain with peaks above $1800 \mathrm{~m}$. It is thus expected that the simulation of the precipitation distribution over the mountainous island will require a proper horizontal resolution able to describe the main terrain features of the island. The second aim of the study is thus to verify that increasing horizontal resolution in zones of complex orography, such as in Madeira island, improve the simulation of the spatial distribution and total precipitation.

This article is divided into four sections as follows. The data, numerical experiments and methodology are described in Section 2, followed by the results and discussion in Section 3, and conclusions in Section 4.

2. Data, numerical experiments and methodology

The observed precipitation over the 2012 autumn was characterized using the 12 meteorological stations (Ponta do Sol (986), Quinta Grande (984), Areeiro (973), Santo da Serra (975), Funchal (522), Caniçal (978), Calheta (990), Lombo da terça (980), Bica da Cana (970), São Vicente (967), Santana (965), and Santana/ S. Jorge (960)), and distributed over the island and belonging to the Portuguese Sea and Atmosphere Institute, IPMA (no weather radar covering the island). The Areeiro weather station (see 
Figure 5c), located in the South-eastern part of the island (altitude of $1590 \mathrm{~m}$, close to the maximum height), allowed us to highlight the 2012 seasonal distribution of the daily precipitation, and to select the precipitating periods that have been simulated in this study (Figure 2a). The second part of the season was more propitious to heavy precipitation events, with rainfall exceeding $100 \mathrm{~mm} \mathrm{day}^{-1}$ in four days. These four events have thus been selected for this study, and simulations of the periods encompassing them have been designed. Table 1 indicates the start and end of each simulation.

The numerical simulations are performed using the non-hydrostatic research model MESO-NH (Lafore et al., 1998). The initial and boundary conditions are provided by the 6-hourly operational ARPEGE analyses (Courtier et al., 1991). A first series of simulations (called hereafter CTRL) are performed using a $1500 \mathrm{~km} \mathrm{x} 1250$ $\mathrm{km}$ grid domain (D1) at $2.5 \mathrm{~km}$ horizontal resolution. For the second series of simulations (called hereafter EXP) a two-way interactive inner domain (D2) at $500 \mathrm{~m}$ horizontal resolution is added prior to the start of the heavy precipitation period (Figure 1). In the CTRL simulations, the model terrain is obtained from the GTOPO30 database, whereas in the EXP simulations it is obtained from the SRTM database. The periods simulated are shown in Figure $2 b-2 e$. The dashed-line rectangles in blue and green represent the simulations with $2.5 \mathrm{~km}$ (CTRL and EXPD1) and $0.5 \mathrm{~km}$ (EXPD2) resolution, respectively. The inner domain is centered over the Madeira island, covering an area of $300 \mathrm{~km} \times 300 \mathrm{~km}$. The vertical grid is composed of 55 height-based terrainfollowing levels. With respect to the previous study of Couto et al. (2012), the horizontal resolutions are increased ( $3 \mathrm{~km} / 1 \mathrm{~km}$ comparing to $2.5 \mathrm{~km} / 0.5 \mathrm{~km}$ here) but the main difference are mostly the larger model domains considered, with about 100 times more grid-points for each domain. More realistic simulations are thus not only expected for precipitation enhanced by the island orography but also for the larger-scale precipitating systems affecting the island.

The physical package is rather similar to the ones successfully used in past studies of heavy precipitation events over complex terrain (e.g. Ducrocq et al., 2008). The model is also able to correctly reproduce the microphysical pattern and dynamical structure of convective systems (e.g., Cohuet et al., 2011; Pujol et al., 2011). The onemoment microphysical scheme predicts the mass mixing ratios of cloud water, rain, graupel, snow, and ice (ICE3; Pinty and Jabouille, 1998). The turbulence scheme is 
based on a 1.5-order closure (Cuxart et al., 2000). Verrelle et al. (2015) pointed out the necessity to deal with horizontal turbulent fluxes at kilometric resolutions for grid mesh smaller than $2 \mathrm{~km}$. Then, in the inner $500 \mathrm{~m}$ resolution domain, the full 3D turbulent fluxes scheme was activated, while in the $2.5 \mathrm{~km}$ domain only the vertical fluxes were considered. Shallow convection is parameterized according to Pergaud et al. (2009) for the $2.5-\mathrm{km}$ domain only. The radiation parametrization is based on the Rapid Radiative Transfer Model (Mlawer et al., 1997).

It is well known that the density of raingauge observations is essential in order to achieve a good quantitative evaluation of the model performance to simulate the complex behaviour of the precipitation over a steep terrain. In our case, there are only observations on the island and with poor coverage in its mountainous interior. Nevertheless, the quality of the simulated accumulated precipitation in each event is assessed against raingauge observations qualitatively and quantitatively using correlation (r), Mean Error (ME), Mean Absolute Error (MAE), and Root Mean Square Error (RMSE), Wilks (2006).

Due to the so-called double-penalty effect, point validation sometimes presents high differences between the observed and high resolution simulated precipitation. Couto et al. (2012) compared, point to point, the temporal evolution of the simulated precipitation with observations. Here, besides the point validation, a very simple neighbourhood verification technique is applied. The assumption of this kind of nontraditional verification strategy is, as explained by Mittermaier (2014), that neighbouring forecast values are just (or nearly) as likely to provide the correct value of the single (central) forecast value. By considering a neighbourhood, a distribution of values is available instead of just one. A good review of spatial verification techniques that do not require the forecasts to exactly match the observations at fine scales may be found in Ebert (2008). In the present verification of event accumulated precipitation, square windows surrounding the observation points were considered, and all the gridded precipitation forecasts inside each window are collected and compared with the respective observed value. The window area corresponds to $3 \times 3$ grid points in the 2.5 $\mathrm{km}$ resolution domain (CTRL and EXPD1), and 15x15 grid points in the inner domain at $0.5 \mathrm{~km}$ resolution (EXPD2). Within this area, the best simulated value ('best point', hereafter), is selected. 
Meteosat Second Generation (MSG) Infrared (IR) 10.8 Brightness Temperature (BT) is used to evaluate the realism of the simulation of the larger-scale cloudy weather systems over the Atlantic Ocean. Chaboureau et al. (2008) showed the ability of the MESO-NH in forecasting cloud cover considering precipitation events over southern and northern Europe. The model infrared brightness temperature is simulated from the temperature, water vapour and hydrometeors using the radiative transfer code RTTOV (Radiative Transfer for Tiros Operational Vertical Sounder, Saunders et al., 2005). Finally, the radiosounding launched each day at the Funchal station (located in the southeast of the island) at 12 UTC is used to evaluate the model ambient conditions over the island.

\section{Results and discussion}

In this section the four periods are presented separately, as well as a discussion of the main aspects found in each one.

\subsection{Periods}

3.1.1. Period 1 (21-23 October 2012): The synoptic situation is characterized by an upper-level cut-off deepening and progressing southward, toward the Azores archipelago, from 21 to 23 October (Figure 3a). Ahead, the frontal system extends from $50^{\circ} \mathrm{N}$ to $30^{\circ} \mathrm{N}$ with embedded deep convection triggered during the afternoon on 22 October and the day after (Figure 4a). The precipitation over the Madeira during this period is associated with the passage of the frontal cloudy system over the island. The observed precipitation over the island was continuous along the entire period, with a weak to moderate rain rate, not exceeding $25 \mathrm{~mm} \mathrm{~h}^{-1}$ (Figure $2 b$ ).

The CTRL and EXP simulations represent quite well the time evolution of the frontal system passage over the island. Figure 4abc show the observed and simulated IR brightness temperature when the front with embedded convection is over the island. The simulations represent the main patterns of the cloudy system, with slightly lesser postfrontal clouds.

Figure 5abc displays the 33-h accumulated surface precipitation over the timewindow indicated by the dashed-line red rectangle in Figure $2 \mathrm{~b}$. The impact of the terrain island on the simulated accumulated precipitation from CTRL and EXP is 
clearly evidenced, with precipitation totals above $100 \mathrm{~mm}$ for terrain height above 1000 $\mathrm{m}$, also in agreement with the raingauge observations (Figure 5c). The EXP simulation and in a lesser extend the CTRL experiment globally overestimate the observed precipitation.

3.1.2. Period 2 (29-30 October 2012): This period was characterized by diffluent flow at $300 \mathrm{hPa}$ over the Madeira island, associated with an upper level cut-off low centered $35^{\circ} \mathrm{W} / 35^{\circ} \mathrm{N}$ (Figure $3 \mathrm{~b}$ ). A large disturbance is associated with the pressure low. The precipitation over the Madeira island is produced by the southern part of the disturbance which progressed eastward while broking away from the main frontal system. The comparison between the model and observed IR brightness temperature shows that both EXP and CTRL represent well the time evolution and extent of the disturbance (not shown).

The high amount of moisture in the lower troposphere was well simulated by the model when compared with the sounding at 12 UTC (Figure 6a). However, above about $2 \mathrm{~km}$, the tropospheric moisture is underestimated in both CTRL and EXP simulations.

The heavy precipitation over the Madeira island occurred in less than 18 hours with records above 30 or even $40 \mathrm{~mm} \mathrm{~h}^{-1}$ in the highest stations (dashed-line red rectangle, Figure 2c). Both CTRL and EXP successfully captured the short extreme rainfall event with maxima over two distinct regions over the central mountains, more specifically over the southern slopes (Figure 5def). The maximum above $300 \mathrm{~mm}$ at Areeiro station was underestimated (eastern top, Figure 5f). The EXP simulation represented the precipitation better than CTRL over the eastern coast. Also, EXP simulates less weak precipitation over the Atlantic Ocean, which seems more in agreement with the raingauge observations along the northern coasts having recorded rain lesser than $25 \mathrm{~mm}$.

3.1.3. Period 3 (04-07 November 2012): For this event, two phases are defined. The first phase corresponds to heavy precipitation in North/North-eastern (NE) regions of the island between 2000 UTC on 4 Nov. and 0700 UTC on 5 Nov. (Figure 2d), and from 0300 to 0500 UTC on 5 Nov. for other stations. The maximum intensities recorded at 
Santana stations are larger than $40 \mathrm{~mm} \mathrm{~h}^{-1}$ (0500 UTC - 05 Nov.). Another convective precipitation period occurred also between 1100 and 1200 UTC. The second phase is characterized by continuous precipitation over the island, more intense between 1800 UTC on 5 Nov. and 1200 UTC on 6 Nov., remaining relatively weak until the end of the period (7 Nov. 1800 UTC). Floods were observed on the northeastern side of the Madeira island. The analysis of the numerical results was performed according to this two phases called PHASE 1 and PHASE 2 hereafter (dashed-line red rectangles, Figure $2 d)$.

The synoptic situation was characterized by an upper-level trough extending from Northern Europe to west of the Canary Islands (Figure 3c-3d). Deep convection formed within the southern part of the cloud belt extending along the right side of the trough axis. The development of deep convection occurred over the ocean and sometimes, transported by the southwesterly flow, reached the island during PHASE 1, but not in PHASE 2. The comparison between observed and simulated IR brightness temperature shows that the simulations capture well the two phases with a T-shape cloud cluster with embedded deep convection during PHASE 1 and elongated cloud systems, some of them being convective, during PHASE 2 (not shown).

The comparison with the radiosoundings shows a very good agreement between the simulations and observations for the moisture content during PHASE 2 (Figure 6c). During PHASE 1, the simulations underestimate the vapour mixing ratio at all levels (Figure 6b).

In PHASE 1 (Figure 5ghi), the very localised heavy precipitation in the NE of the island was simulated in both experiments, also coherent with the region where flood was reported in the late morning on 05 November. Unfortunately, there are no observations to evaluate the model performance for the maximum in the North-western region, but considering the NE maximum and most of the stations, the values measured and simulated are in good agreement (Figure 5i). For this event, the EXPD2 rainfall pattern evidences the usefulness of a better representation of the local orography for a more realistic result of the spatial distribution of the precipitation. The maximums between 200 and $300 \mathrm{~mm}$ are observed over the terrain slopes and in large part below a height of $500 \mathrm{~m}$. This feature is not so well represented in the $2.5 \mathrm{~km}$ domains by CTRL, which underestimates the extent of precipitation over the island. 
In PHASE 2 (Figure 5jkl), large amounts of accumulated precipitation were recorded during 54 hours and simulated over the central region of the island and extending northward over the ocean in the EXP simulations. The distribution of precipitation over the island as deduced from the observations is globally overestimated by the model, and in larger extend by the EXP simulation. It is worth mentioning that the simulations perform well although the long integration period (total of $78 \mathrm{~h}$ ).

3.1.4. Period 4 (23-27 November 2012): It comprises a total of 90 hours (Figure 2e). However, we focus in this study on the period between 1700 UTC on 24 Nov. to 0800 UTC on 25 Nov. (dashed-line red rectangle, Figure 2e), when heavy rainfall was recorded with maxima above $30 \mathrm{~mm} \mathrm{~h}^{-1}$, in some cases even $40 \mathrm{~mm} \mathrm{~h}^{-1}$.

The convective clouds developed on the right side of an upper-level short wave trough associated to stratospheric air intrusion into the troposphere (Figure 3e-3f), few hours before the clouds start to curve cyclonically. Figure 4d clearly shows the dry air intrusion and cloud presenting a spiral configuration in the centre of the cyclonic circulation. This structure is well represented in both simulations (Figure 4e-4f), but more quickly developed in the EXPD1. The system had a rapid deepening and in the subsequent hours the cyclonic circulation throughout the troposphere was observed, with the cut-off low centred to the southward of the Madeira. The system moved to South-eastward, and dissipated toward the Canary archipelago.

The moisture content in the troposphere was well simulated on 24 Nov. (Figure 6d) and 25 Nov. (Figure 6e). However, in the latter the CTRL simulation overestimates the amounts at lower levels.

The simulations represent very well the rainfall pattern over the Madeira island with the higher precipitation over the highlands, except for the two eastern stations (Figure 5mno). From these two stations, it may be inferred that the simulations overestimate the large area of heavy precipitation to east of the island, although no observations are available to confirm it. EXPD2 provides details in the precipitation field over the island that agree better with the raingauge values than CTRL.

\subsubsection{Model performance}


Figure 7 shows the comparison between the total accumulated precipitation in the meteorological stations and in each simulation for the periods highlighted in Figure 2 from the dashed-line red rectangle.

When comparing the raingauge observations with the simulations at the nearest grid point (left column), some differences may be observed, with overestimation (Figure $7 \mathrm{a}$ and $7 \mathrm{~g}$ ), or underestimation (Figure $7 \mathrm{c}$ ) by the model. The right column of Figure 7 shows the results obtained when the "best point" in the neighbour area surrounding the observation site (see Section 2) is selected. The differences are significantly reduced, indicating that even with a punctual slight under- or overestimation, the model well simulated quantitatively the accumulated precipitation at least at some point near the station, i.e. no more than $3.75 \mathrm{~km}$ away in each axis direction.

The same feature is observed in the errors between the simulated and observed accumulated precipitation, presented in Table 2. In general, a high positive correlation is verified, with values close to 1 when the "best point" near the station is considered. In the case of the other scores, for the station nearest grid points, considerable differences (positive or negative) also indicate that the model tends to under or overestimate the total accumulated precipitation at these exact locations. For the RMSE, as an example, the PHASE 2 of period 3 (3-PH2 in Table 2) presents the largest differences between the model and observation, as a consequence of the overestimation showed in Figure $7 \mathrm{~g}$. For the best point near the station, these errors are also greatly reduced and, in general, they are lesser for the simulation at $0.5 \mathrm{~km}$ resolution (EXPD2). Therefore, the model successfully captured the totals of accumulated precipitation, despite some horizontal displacement.

\subsection{Discussion}

Considering the results for the four periods, it is shown that the significant accumulated precipitation over the Madeira occurred under different synoptic environments. The general structure of the cloudy systems over the ocean associated to these synoptic situations was well reproduced by MESO-NH. The rainfall periods clearly express the spatial-temporal variability of how heavy rainfall occurred over the island. For example, weak and continuous precipitation occurred during 48 hours, extreme precipitation during approximately 18 hours, heavy precipitation in just a few 
hours and in high amount resulting from a persistent moderate precipitation for several hours. The MESO-NH also reproduces successfully the spatial distribution of the precipitation over the island, better at $500 \mathrm{~m}$ horizontal resolution. The most interesting result of this study, identified from Figure 5, is the different rainfall patterns over the island, a question not discussed before about precipitation over the Madeira. This difference is summarized schematically in Figure 8. The maximums of accumulated precipitation are concentrated in different altitudes and slopes of the island. The accumulated precipitation is concentrated over the central peaks above a height of 1000 $\mathrm{m}$ (period 1, Figure 8a), or still in the highlands but more localized over the southern slopes (periods 2 and 4, Figure 8b). In opposition, the precipitation in the period 3 occurred in the northern slopes (Figures 8c and 8d). In PHASE 1 of this event, the localised precipitation occurred mainly in the NE coastal plain below a height of 1000 $\mathrm{m}$ (Figure 8d), contrasting with the precipitation in the regions above $1000 \mathrm{~m}$ in PHASE 2 (Figure 8c).

\section{Conclusions}

In this article, a set of eight numerical simulations for all significant rainfall periods in the Madeira island during the autumn 2012 were presented and evaluated for two different horizontal resolutions over large domain.

When confronted with the few observational data available, it was demonstrated the ability of the model to represent the ambient conditions near the island, and the main structure of the different cloudy weather systems over the surrounding ocean, and that for four distinct synoptic situations.

Regarding the accumulated precipitation results, the MESO-NH model was able to successfully capture the strong impact of the local mountains in the distribution and volume of the rainfall over the Madeira at both horizontal resolutions. The simulations using $0.5 \mathrm{~km}$ grid spacing showed more realistic results when compared with the observations. The under or overestimation of the accumulated precipitation was considered acceptable taken into account the duration of the numerical experiments which is quite long as regard the predictability expected at this resolution and for convection. 
Overall, beside the good representation of the events by the MESO-NH, the most important point underscored is the different rainfall patterns, which showed significant precipitation occurring in distinct regions over the island. The accumulated precipitation concentrated above or below a height of $1000 \mathrm{~m}$. In the first case (above $1000 \mathrm{~m}$ ), rainfall was observed in three regions, southern slopes, central peaks, and northern slopes, while in the second case (below $1000 \mathrm{~m}$ ), localised precipitation occurred mainly in the NE coastal plain. Improving the knowledge about the spatial distribution of significant precipitation over the Madeira is an important issue, mainly because sometimes heavy rainfall events may induce floods, as occurred during the period 3, moreover, in a different region when comparing with the disaster on February 20, 2010. Also, it shows that the significant precipitation during the autumn 2012 was strongly related to the local orography, embedded or not within an extra-tropical weather system.

In the near future, the simulations will be used to investigate in detail the orographic mechanisms associated to these rainfall events that explain the various precipitation patterns over the island.

\section{Acknowledgements}

This study was funded by FCT (Fundação para a Ciência e a Tecnologia) through grant SFRH/BD/81952/2011 and by the Institute of Earth Sciences (ICT), under contract with FCT. We acknowledge the Météo-France for the supply of the data and the HPC facility and also the MESO-NH support team, as well as the Portuguese Sea and Atmosphere Institute (IPMA) for providing the raingauge data.

\section{References}

Chaboureau J.-P., Söhne, N., Pinty, J.-P., Meirold-Mautner, I., Defer, E., Prigent, C., Pardo, J.R., Mech, M., Crewell, S., 2008. A Midlatitude Precipitating Cloud Database Validated with Satellite Observations. J. Appl. Meteor. Climatol., 47, 1337-1353. DOI: http://dx.doi.org/10.1175/2007JAMC1731.1. 
Chen, C.-S., Lin, Y.-L., Peng, W.-C., Liu, C.-L., 2010. Investigation of a heavy rainfall event over southwestern Taiwan associated with a subsynoptic cyclone during the 2003 Mei-Yu season. Atmos. Res., 95, 235-254. DOI: 10.1016/j.atmosres.2009.10.003.

Chen, C.-S., Lin, Y.-L., Hsu, N.-N., Liu, C.-L., Chen, C.-Y., 2011. Orographic effects on localized heavy rainfall events over southwestern Taiwan on 27 and 28 during the Post-Mei-Yu season. Atmos. Res., 101, 595-610. DOI: 10.1016/j.atmosres.2012.10.008.

Cohuet, J.B., Romero, R., Homar, V., Ducrocq, V., Ramis, C., 2011. Initiation of a severe thunderstorm over the Mediterranean Sea, Atmos. Res., 100, 603-620. DOI: http://dx.doi.org/10.1016/j.atmosres.2010.11.002.

Courtier, P., Freydier, C., Geleyn, J.-F., Rabier, F., Rochas, M., 1991. The Arpege project at Meteo France. In Numerical methods in atmospheric models, ECMWF Seminar Proceedings, 9-13 September 1991, ECMWF, Shinfield Park, Reading, UK, pp. 193-231.

Couto, F.T., Salgado, R., Costa, M.J., 2012. Analysis of intense rainfall events on Madeira Island during the 2009/2010 winter, Nat. Hazards Earth Syst. Sci., 12, 22252240. DOI: 10.5194/nhess-12-2225-2012.

Couto, F.T., Salgado, R., Costa, M.J., Prior, V., 2015. Precipitation in the Madeira Island over a 10-year period and the meridional water vapour transport during the winter seasons. Int. J. Climatol., In press. DOI: 10.1002/joc.4243.

Cuxart, J., Bougeault, P., Redelsperger, J.-L., 2000. A turbulence scheme allowing for mesoscale and large-eddy simulations. Q. J. R. Meteorol. Soc., 126, 1-30. DOI: 10.1002/qj.49712656202.

Ducrocq, V., Nuissier, O., Ricard, D., Lebeaupin, C., Thouvenin, T., 2008. A numerical study of three catastrophic precipitating events over southern France. II: Mesoscale triggering and stationary factors. Q. J. R. Meteorol. Soc., 134, 131-145. DOI: 10.1002/qj.199. 
Ebert, E. E., 2008. Fuzzy verification of high-resolution gridded forecasts: a review and proposed framework. Met. Apps, 15, 51-64. DOI: 10.1002/met.25.

Lafore, J.P., Stein, J., Asencio, N., Bougeault, P., Ducrocq, V., Duron, J., Fischer, C., Héreil, P., Mascart, P., Masson, V., Pinty, J.P., Redelsperger, J.L., Richard, E., VilàGuerau de Arellano, J., 1998. The Meso-NH Atmospheric Simulation System. Part I: adiabatic formulation and control simulations, Ann. Geophys., 16, 90-109. DOI: $10.1007 / \mathrm{s} 00585-997-0090-6$.

Lee, K.-O., Shimizu, S., Maki, M., You, C.-H., Uyeda, H., Lee, D.-I., 2010. Enhancement mechanism of the 30 June 2006 precipitation system observed over the northwestern slope of Mt. Halla, Jeju Island, Korea. Atmos. Res., 97, 343-358. DOI: 10.1016/j.atmosres.2010.04.008.

Lee, K.-O., Uyeda, H., Lee, D.-I., 2014. Microphysical structures associated with enhancement of convective cells over Mt. Halla, Jeju Island, Korea on 6 July 2007. Atmos. Res., 135-136, 76-90. DOI: 10.1016/j.atmosres.2013.08.012.

Levizzani, V., Laviola, S., Cattani, E., Costa, M.J., 2013. Extreme precipitation on the Island of Madeira on 20 February 2010 as seen by satellite passive microwave sounders. Eur. J. Remote Sens., 46, 475-489. DOI: 10.5721/EuJRS20134628.

Lin, Y.-L., Chiao, S., Wang, T.-A., Kaplan M. L., Weglarz, R.P., 2001. Some Common Ingredients for Heavy Orographic Rainfall. Wea. Forecasting, 16, 633-660. DOI: http://dx.doi.org/10.1175/1520-0434(2001)016<0633:SCIFHO>2.0.CO;2.

Luna, T., Rocha, A., Carvalho, A.C., Ferreira, J.A., Sousa, J., 2011. Modelling the extreme precipitation event over Madeira Island on 20 February 2010, Nat. Hazards Earth Syst. Sci., 11, 2437-2452. DOI: 10.5194/nhess-11-2437-2011.

Mittermaier, M.P., 2014. A strategy for verifying near-convection-resolving forecasts at observing sites. Wea. Forecasting. 29(2), 185-204. DOI: 10.1175/WAF-D-12-00075.1. 
Mlawer, E.J., Taubman, S.J., Brown, P.D., Iacono, M.J., Clough, S.A., 1997. Radiative transfer for inhomogeneous atmospheres: RRTM, a validated correlated-k model for the longwave. J. Geophys. Res., 102(D14), 16 663-16 682. DOI: 10.1029/97JD00237.

Pergaud, J., Masson, V., Malardel, S., Couvreux, F., 2009. A parameterization of dry thermals and shallow cumuli for mesoscale numerical weather prediction. Bound-Lay Meteorol., 132, 83-106. DOI: 10.1007/s10546-009-9388-0.

Pinty, J.-P., Jabouille, P., 1998. A mixed-phase cloud parameterization for use in a mesoscale non hydrostatic model: Simulations of a squall line and of orographic precipitation. Proceedings of Conference on Clouds Physics, 17-21 August 1998, Everett, USA, 217-220.

Pujol, O., Lascaux, F., Georgis, J.F., 2011. Kinematics and microphysics of MAP-IOP3 event from radar observations and Meso-NH simulations, Atmos. Res., 101, 124-142, DOI: http://dx.doi.org/10.1016/j.atmosres.2011.02.004.

Saunders, R., Matricardi, M., Brunel, P., English, S., Bauer, P., O'Keeffe, U., Francis, P., Rayer, P., 2005. RTTOV-8 science and validation report. NWP SAF Report, 41 pages, Tech. Rep.

Smith, R.B., Minder, J.R., Nugent, A.D., Storelvmo, T., Kirshbaum, D.J., Warren, R., Lareau, N., Palany, P., James, A., French, J., 2012. Orographic Precipitation in the Tropics: The Dominica Experiment. Bull. Am. Meteorol. Soc., 93, 1567-1579. DOI: http://dx.doi.org/10.1175/BAMS-D-11-00194.1.

Verrelle, A., Ricard, D., Lac, C., 2015. Sensitivity of high-resolution idealized simulations of thunderstorms to horizontal resolution and turbulence parametrization. Q.J.R. Meteorol. Soc., 141: 433-448. DOI: 10.1002/qj.2363.

Wang, C.-C., Hsu, J. C.-S., Chen, G. T.-J., Lee, D.-I., 2014a. A Study of Two Propagating Heavy-Rainfall Episodes near Taiwan during SoWMEX/TiMREX IOP-8 in June 2008. Part I: Synoptic Evolution, Episode Propagation, and Model Control 
Simulation. Mon. Weather Rev., 142, 2619-2643. DOI: http://dx.doi.org/10.1175/MWR-D-13-00331.1.

Wang, C.-C., Hsu, J. C.-S., Chen, G. T.-J., Lee, D.-I., 2014b. A Study of Two Propagating Heavy-Rainfall Episodes near Taiwan during SoWMEX/TiMREX IOP-8 in June 2008. Part II: Sensitivity Tests on the Roles of Synoptic Conditions and Topographic Effects. Mon. Weather Rev., 142, 2644-2664. DOI: http://dx.doi.org/10.1175/MWR-D-13-00330.1.

Wilks, D. S., 2006. Statistical Methods in the Atmospheric Sciences. International Geophysics Series, Volume 91 (2nd edition), Academic Press, 627 pp. 


\section{Figure captions}

Figure 1. Location of the Madeira island and the MESO-NH configuration. The larger domain (D1) at $2.5 \mathrm{~km}$ horizontal resolution, and the inner domain (D2) at $0.5 \mathrm{~km}$ grid spacing. The orography was obtained from the SRTM database.

Figure 2. Raingauge observations: (a) daily accumulated precipitation at Areeiro station during the autumn 2012; hourly accumulated precipitation at the meteorological stations (see text) during the (b) period 1, (c) period 2, (d) period 3, and (e) period 4. The simulated periods as described in Table 1 are represented as dashed-line blue and dashed-line green boxes for the $2.5-\mathrm{km}$ and $0.5-\mathrm{km}$ model domains, respectively. The dashed-line red boxes delineate the periods used for accumulated precipitation presented in Figure 5.

Figure 3. Operational ARPEGE analyses at 0000 UTC with 2.0 PVU surface (shaded), geopotential height at $500 \mathrm{hPa}$ (blue solid lines) and wind (arrows; above $10 \mathrm{~m} \mathrm{~s}^{-1}$ ) at 300 hPa: (a) 23 Oct. 2012 (period 1); (b) 30 Oct. 2012 (period 2); (c) 05 Nov. 2012 (period 3 - PHASE 1); (d) 06 Nov. 2012 (period 3 - PHASE 2); (e) 24 Nov. 2012 (period 4); and (f) 25 Nov. 2012 (period 4).

Figure 4. Infrared $10.8 \mu \mathrm{m}$ brightness temperature $\left({ }^{\circ} \mathrm{C}\right)$ obtained from the Meteosat Second Generation observation (left column), and simulated by CTRL (middle column) and EXP- domain D1 (right column) at 0500 UTC, 23 October 2012: (a), (b), and (c); at 1100 UTC, 25 November 2012: (d), (e) and (f).

Figure 5. Accumulated precipitation from MESO-NH (coloured areas) CTRL (left column), EXP- domain D1 (middle column), and EXP- domain D2 (right column) simulations during the periods highlighted in Figure $2 \mathrm{~b}-2 \mathrm{e}$ (dashed-line red boxes): period 1: (a), (b), and (c); period 2: (d), (e), and (f); period 3: (g), (h), and (i) for PHASE 1, and (j), (k), and (l) for PHASE 2; and period 4: (m), (n) and (o). The squares in the right column represent the accumulated precipitation at the meteorological stations. The solid lines represent the model terrain (isoline interval: $500 \mathrm{~m}$ ) obtained from the GTOPO30 database for CTRL (2.5 km resolution) and SRTM database for EXP (D1, $2.5 \mathrm{~km}$ resolution; $\mathrm{D} 2,0.5 \mathrm{~km}$ resolution).

Figure 6. Water vapour mixing ratio from the radiosoundings (OBS, green line) and simulations (CTRL, red line; EXPD1, blue line; EXPD2, yellow dashed-line) at 1200 UTC for (a) period 2 (30 Oct. 2012); (b) period 3, PHASE 1 (05 Nov. 2012); (c) period 3, PHASE 2 (06 Nov. 2012); (d) period 4 (24 Nov. 2012); and (e) period 4 (25 Nov. 2012).

Figure 7. Comparison between the accumulated precipitation at the meteorological stations and those simulated for the nearest grid-point (left column), and for the "best point" in the neighbourhood of the station (right column). The periods of accumulated precipitation are the same showed from the dashed-line red rectangle in the Figure 2.

Figure 8. Schematic representation of the rainfall patterns over the Madeira verified from the periods simulated. Maximums of accumulated precipitation occurred above a height of $1000 \mathrm{~m}$ and concentrated over (a) central peaks, (b) southern slope, and (c) 
northern slope; and (d) below a height of $1000 \mathrm{~m}$ in the northern slope. The solid lines represent the terrain in each $500 \mathrm{~m}$. 


\section{Figure 1}

ZS (m)

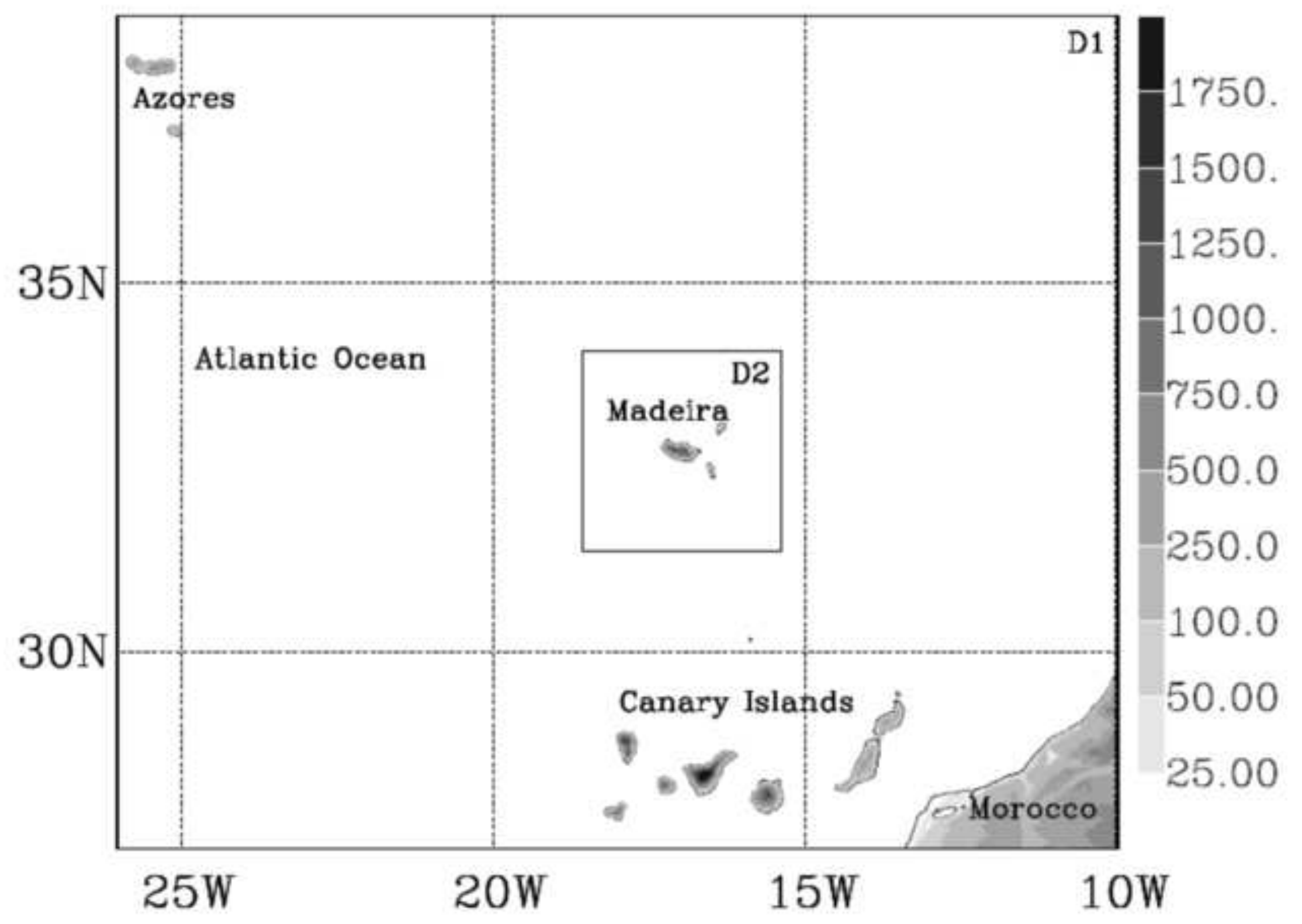


Figure 2

a)

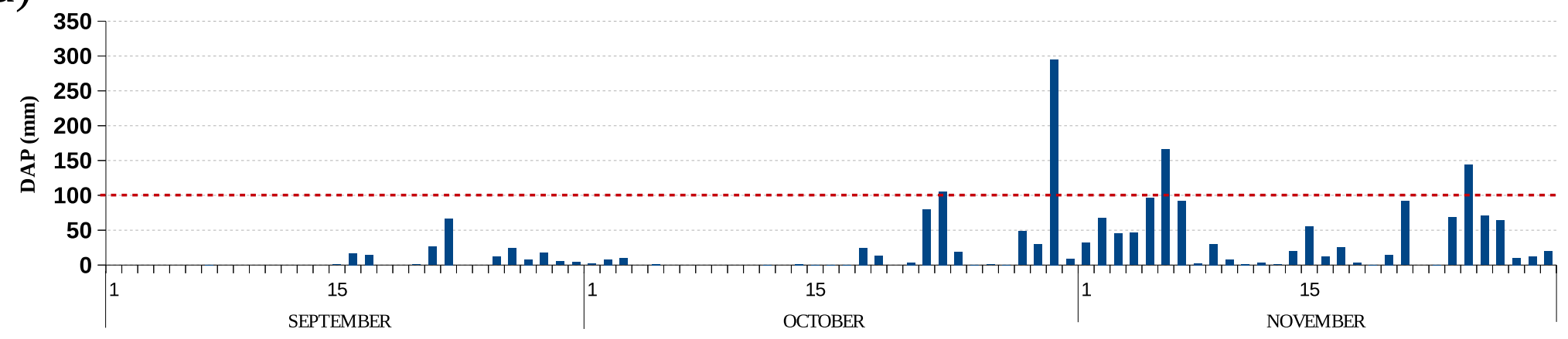

b)

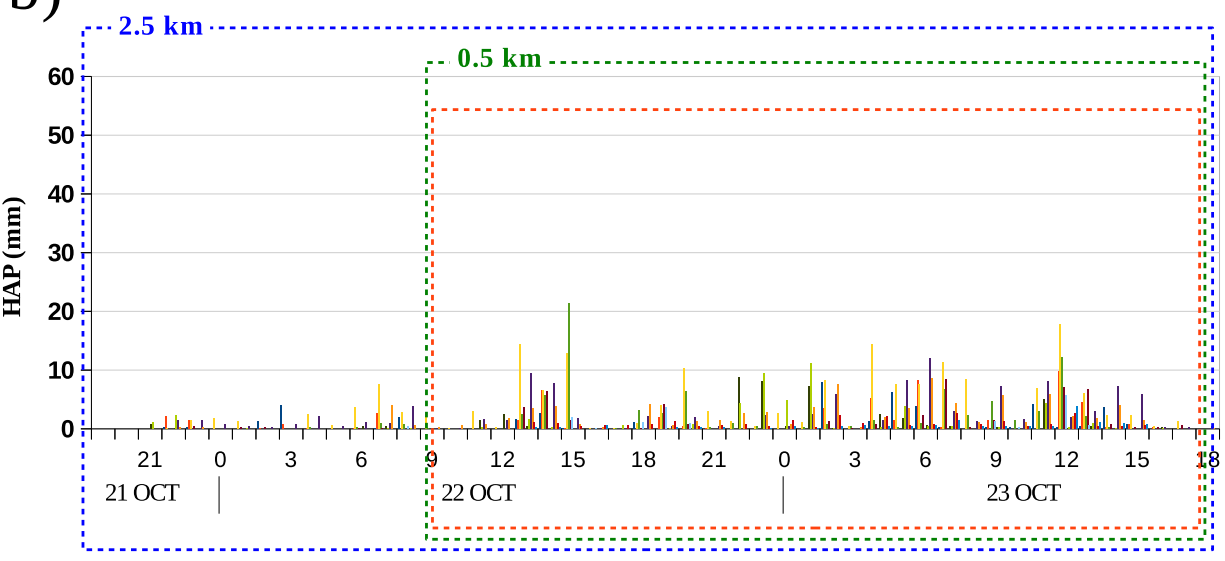

c)

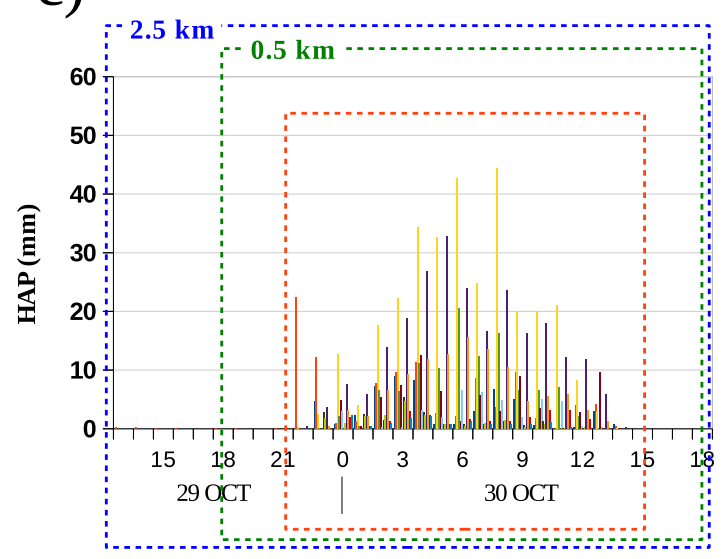

METEOROLOGICAL STAT IONS

d)

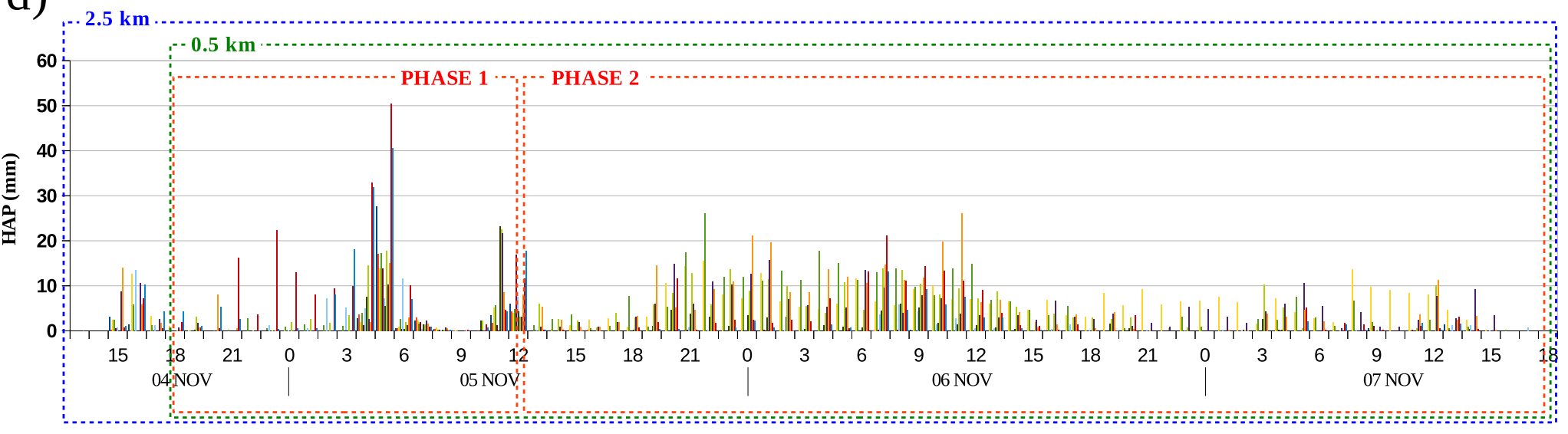

e)

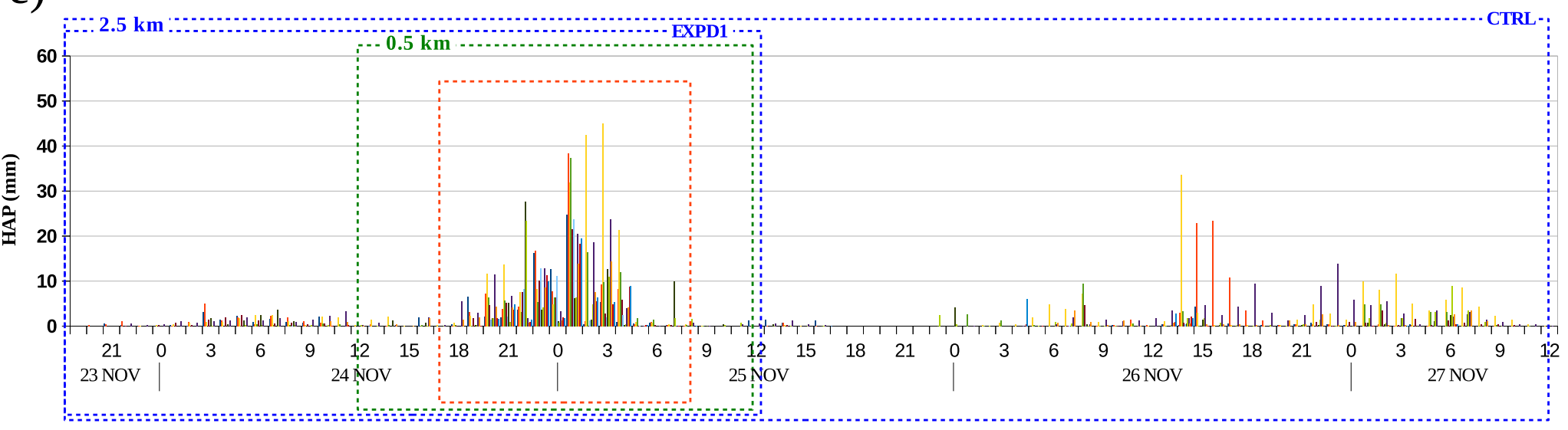


a)

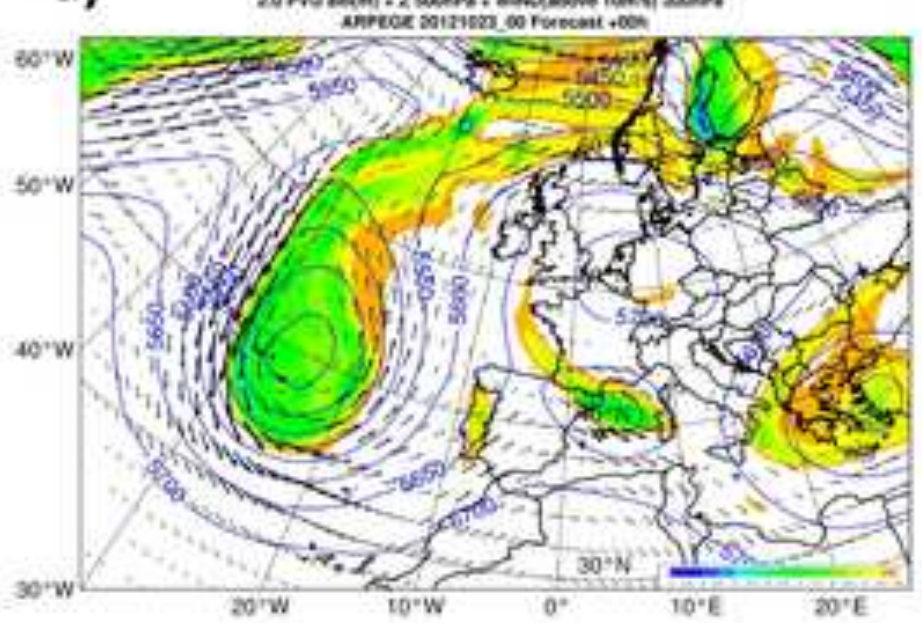

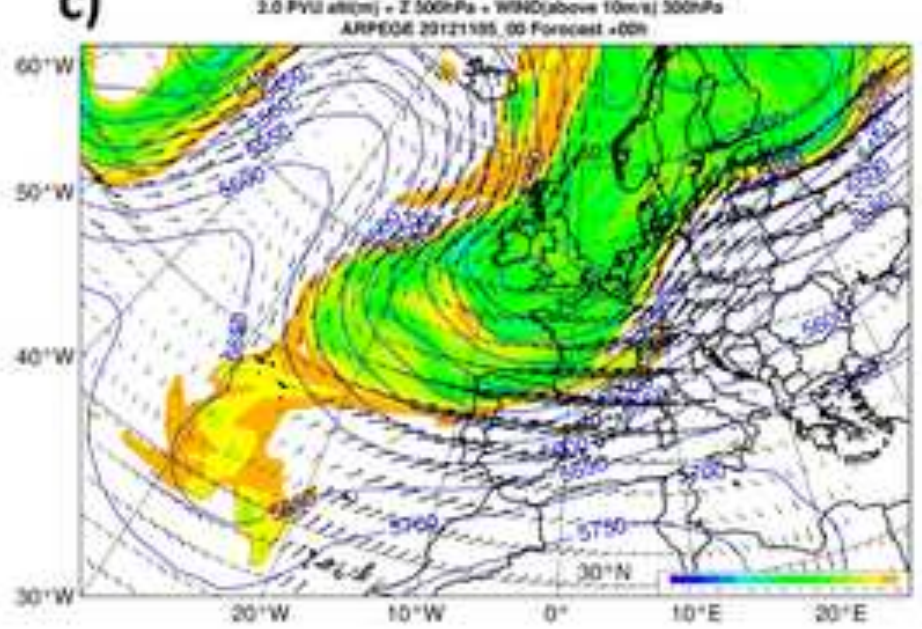

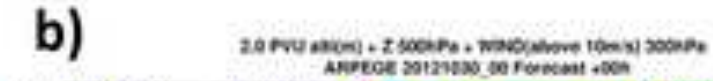

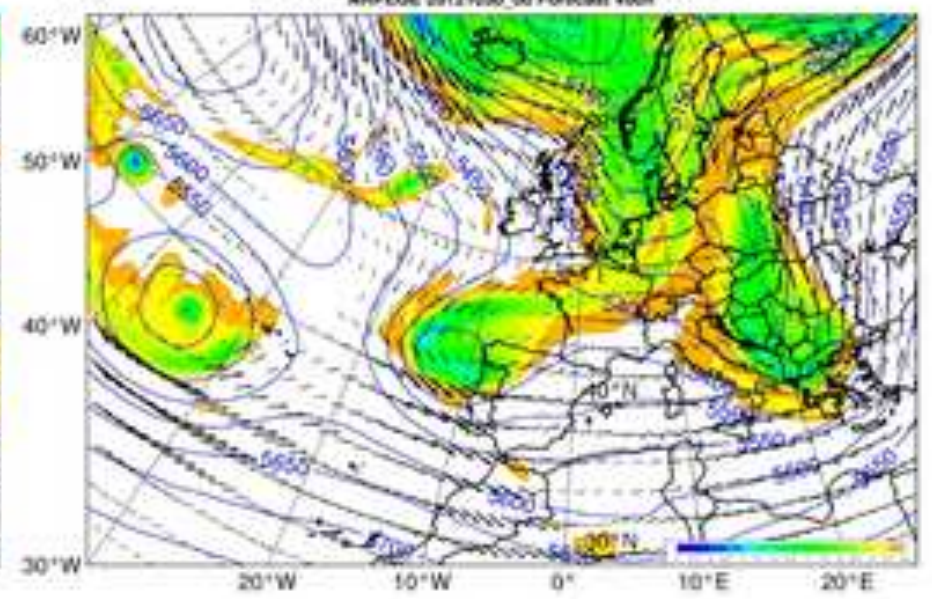

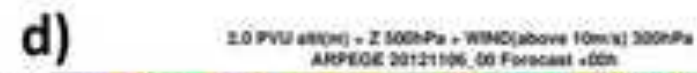
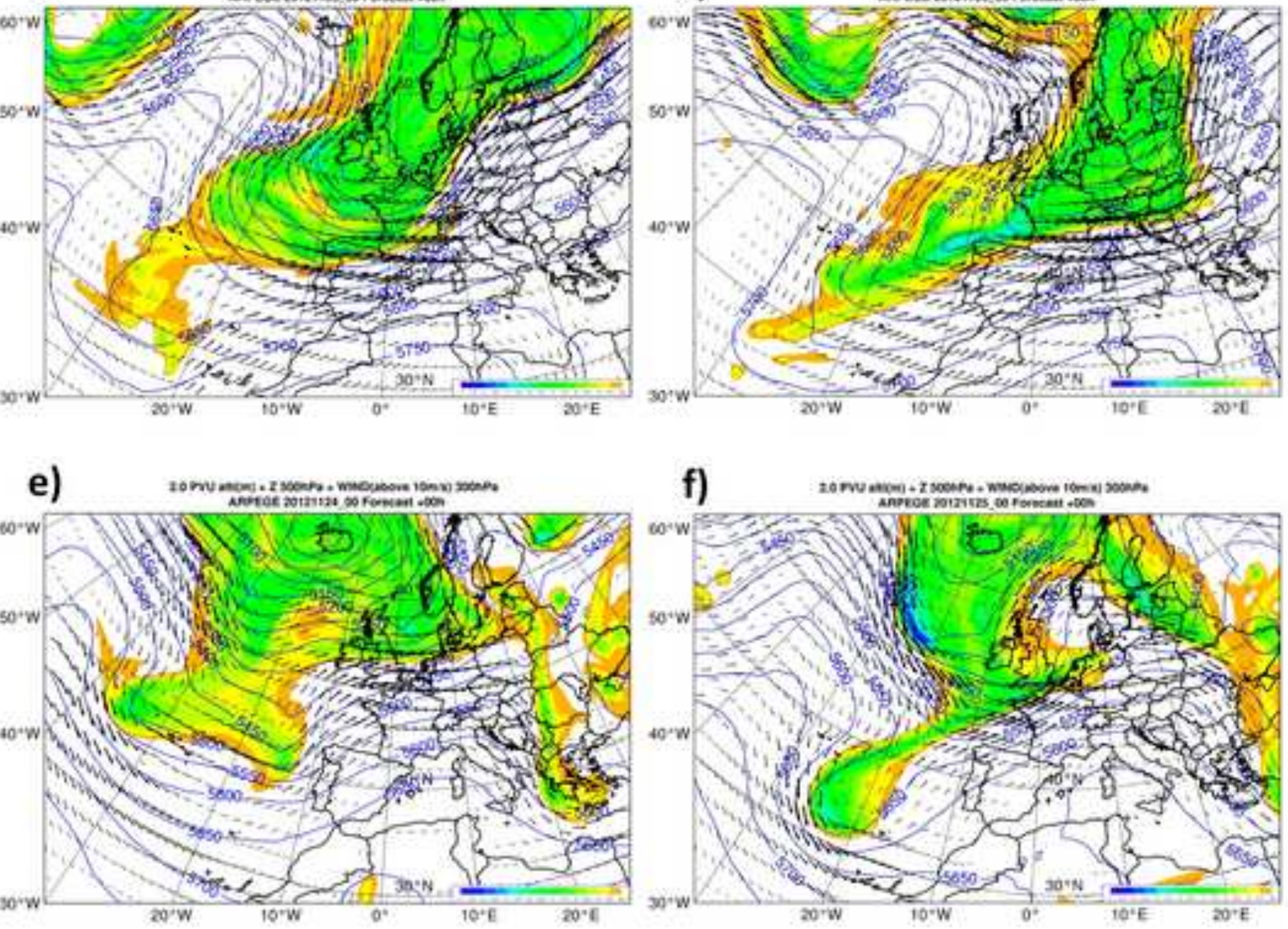

f)

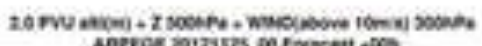

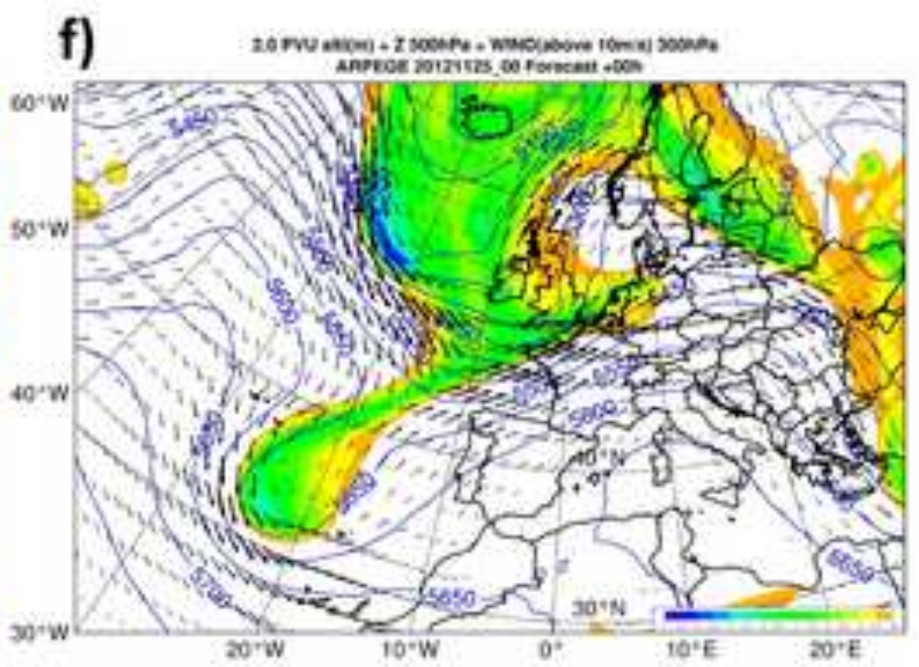


a) OBS (0500 UTC - 23 OCT 2012)

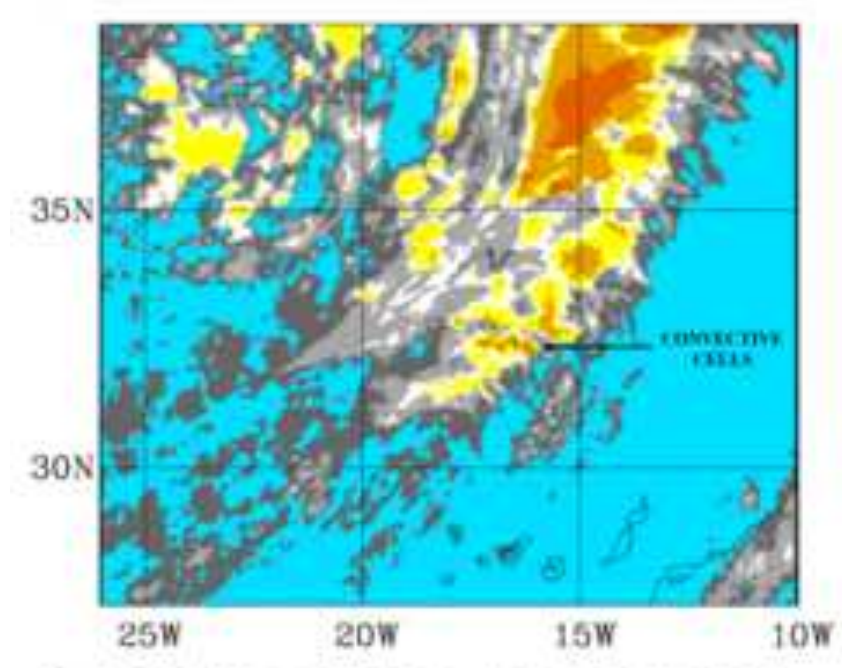

d) OBS (1100 UTC - 25 NOV 2012)

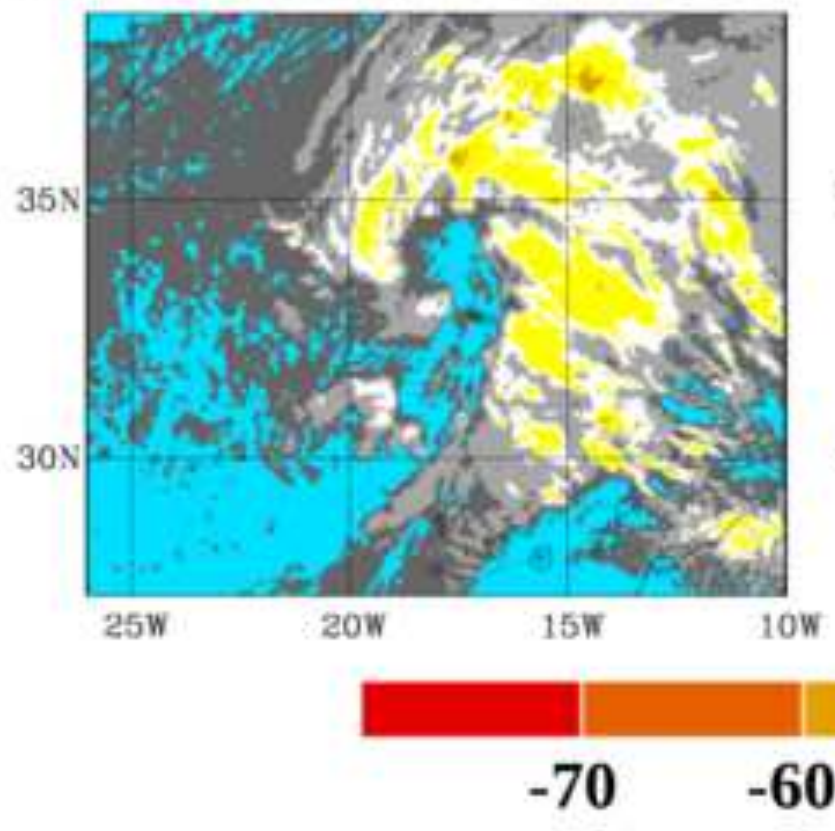

$-70-60$ b) CTRL

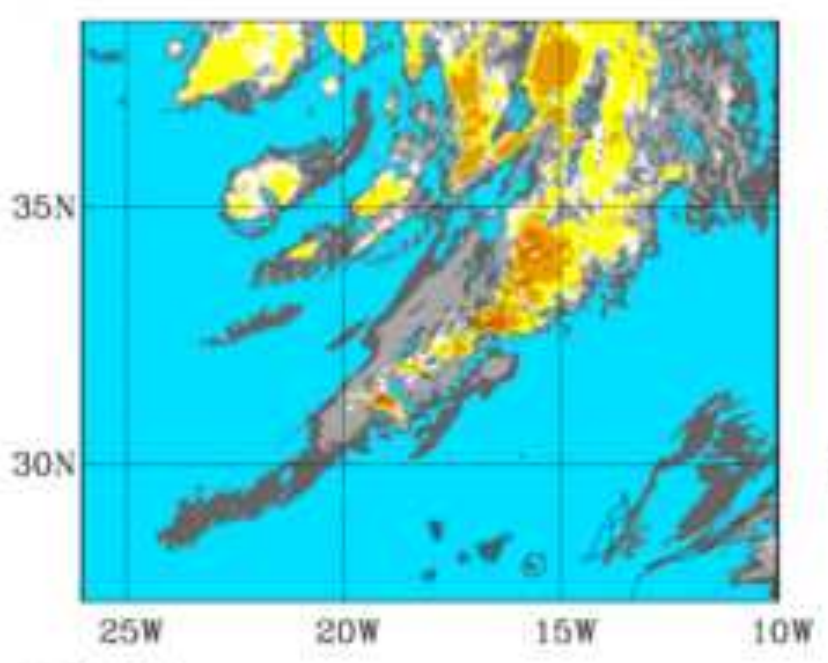

e) CTRL

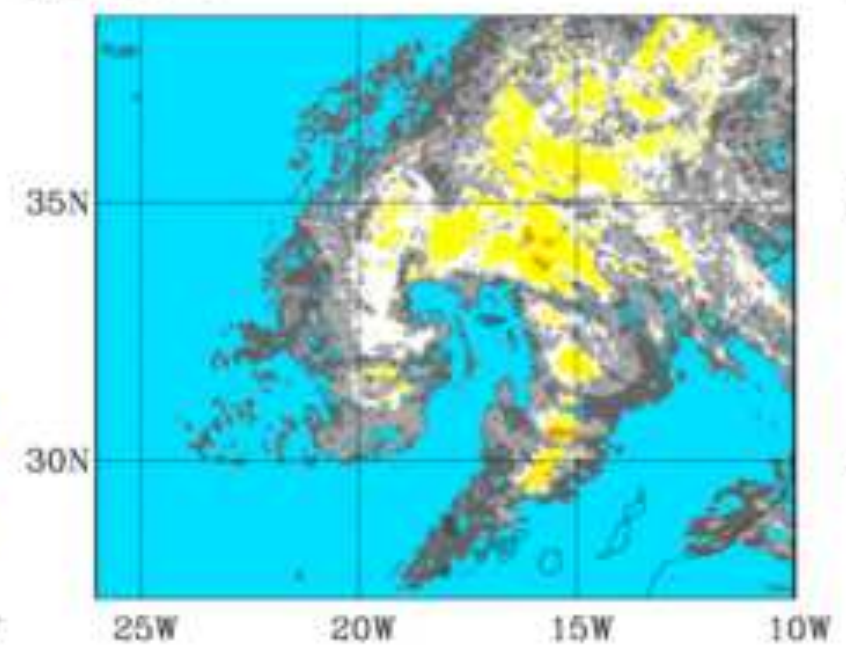

c) EXPD1

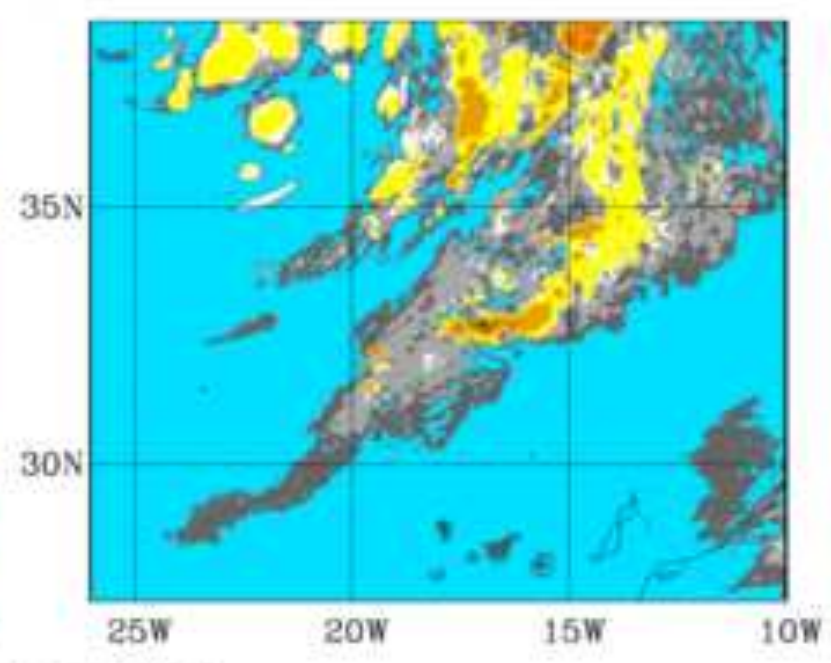

f) EXPD1

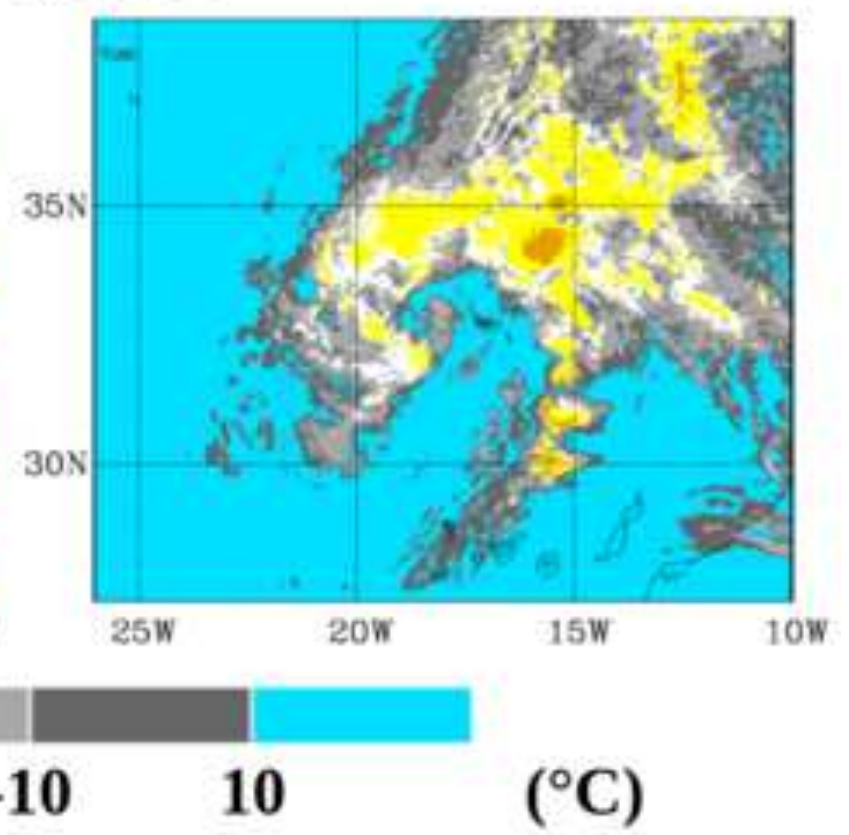

\section{$-10$}

10
$-50$

$-40$

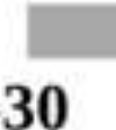



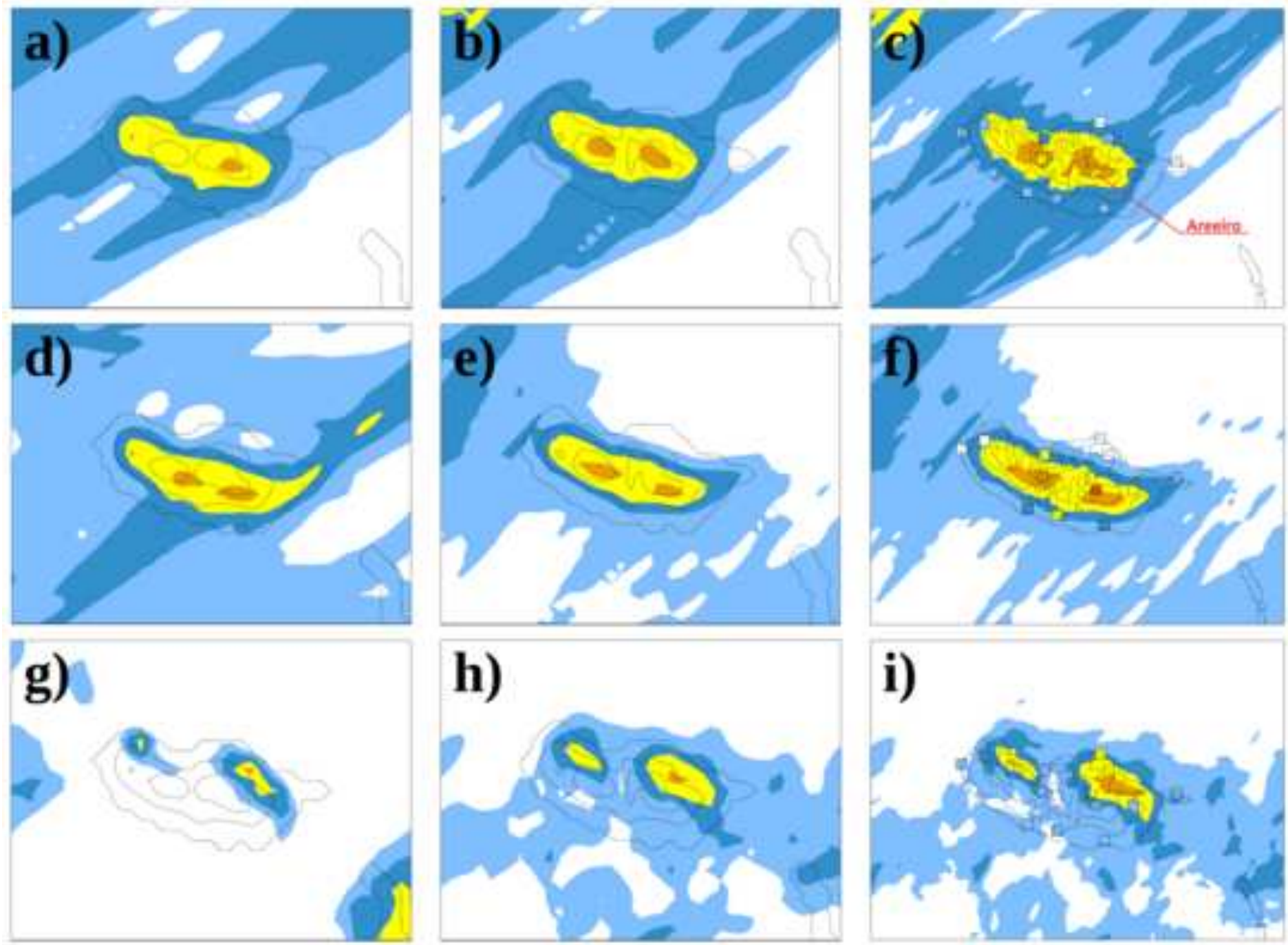

h)
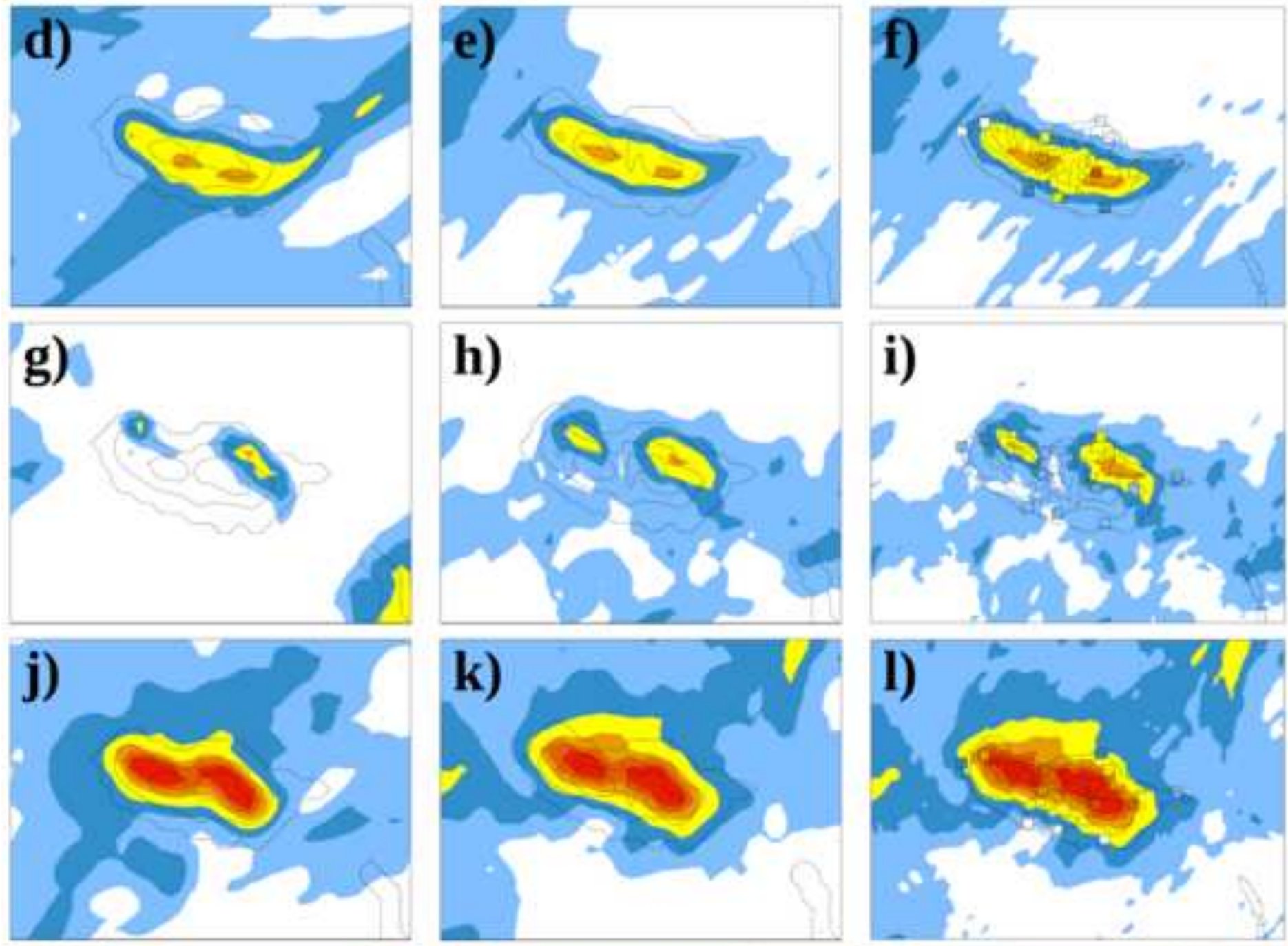

\section{i)}
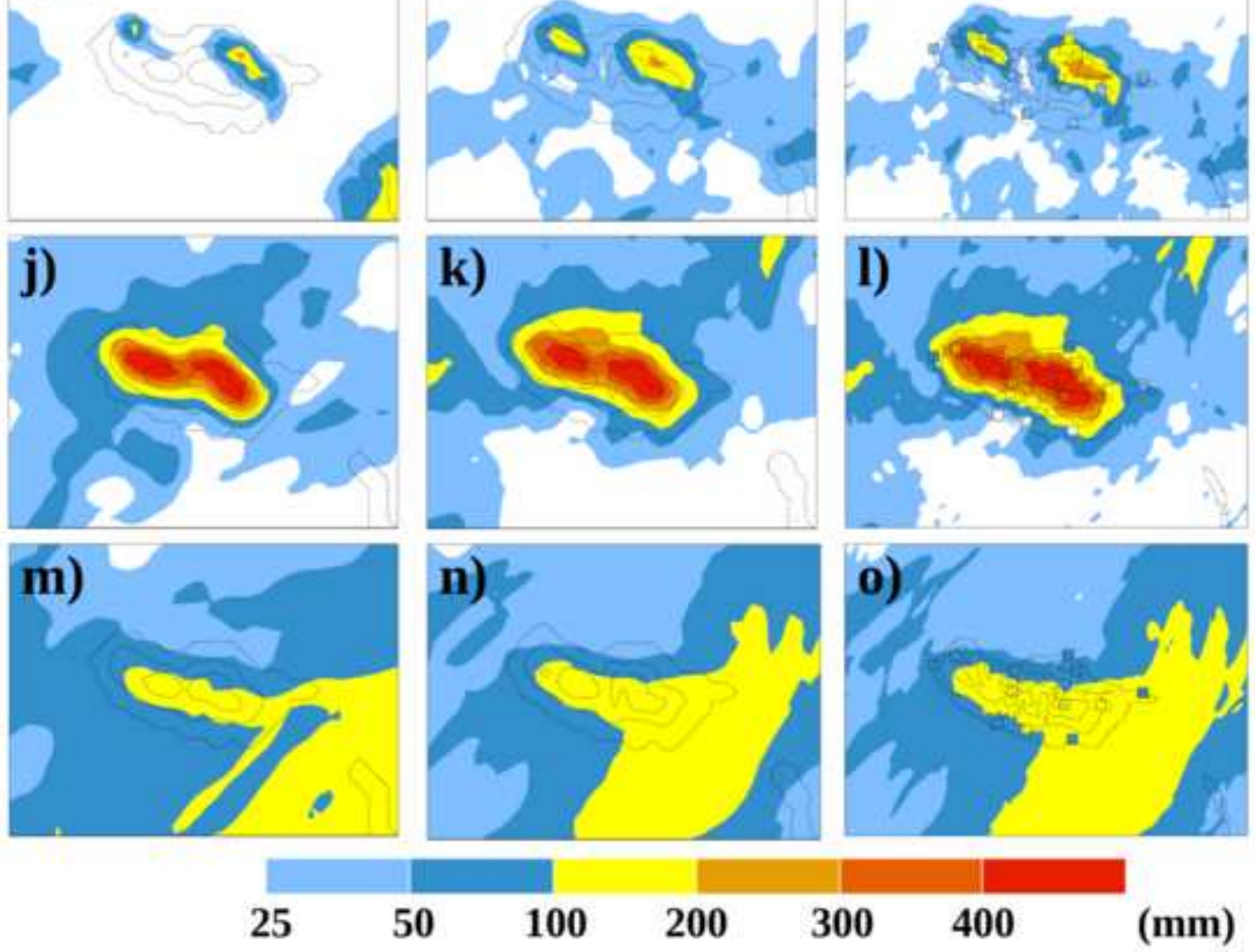

300

400

(mm) 
Figure 6

a)

$$
\text { | }
$$

b)

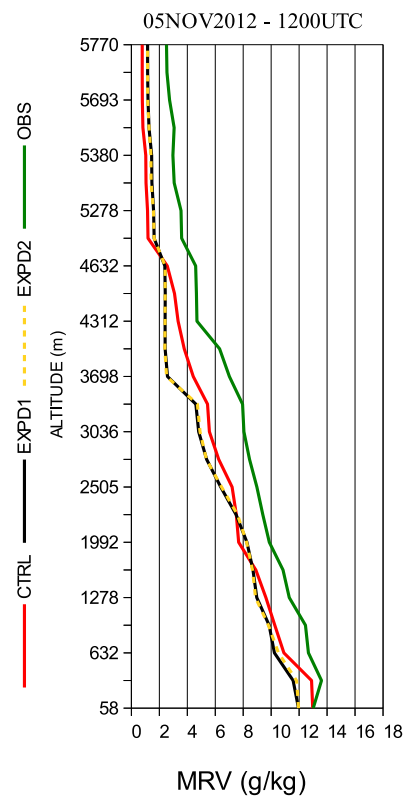

c)

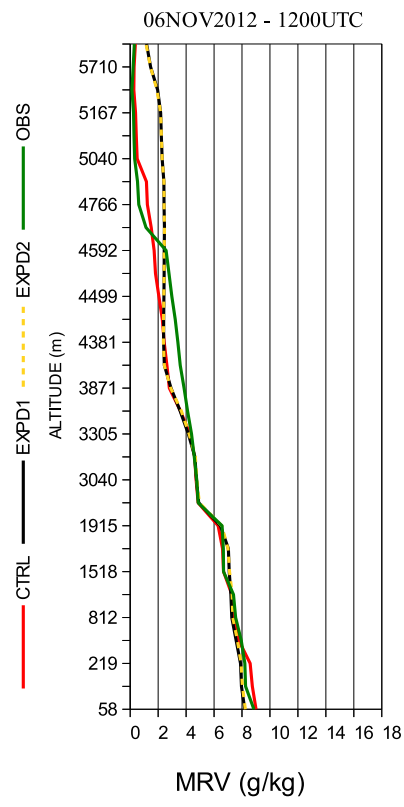

d)

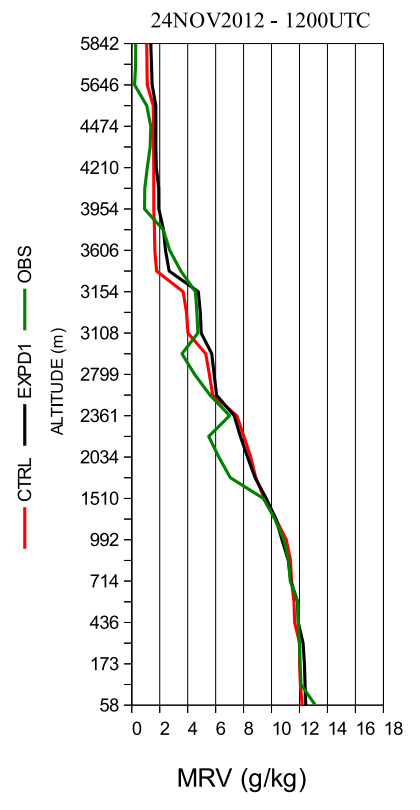

e)

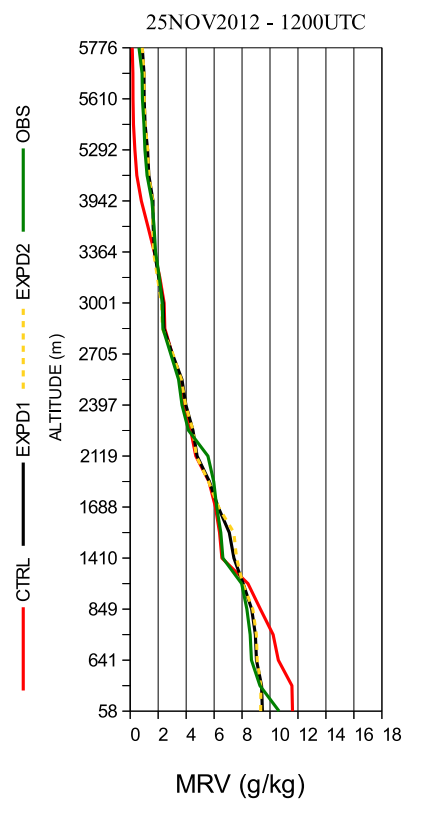


Figure 7

a)

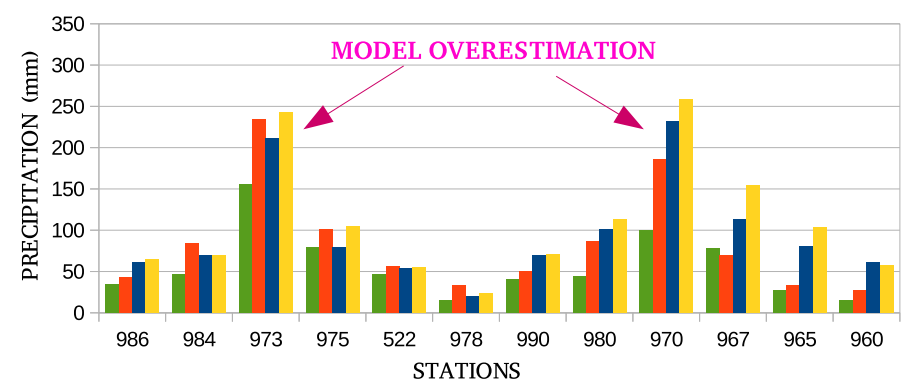

c)

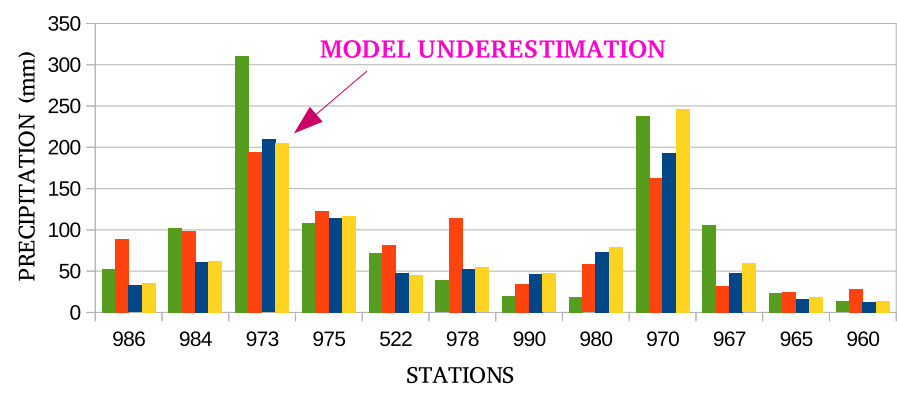

e)

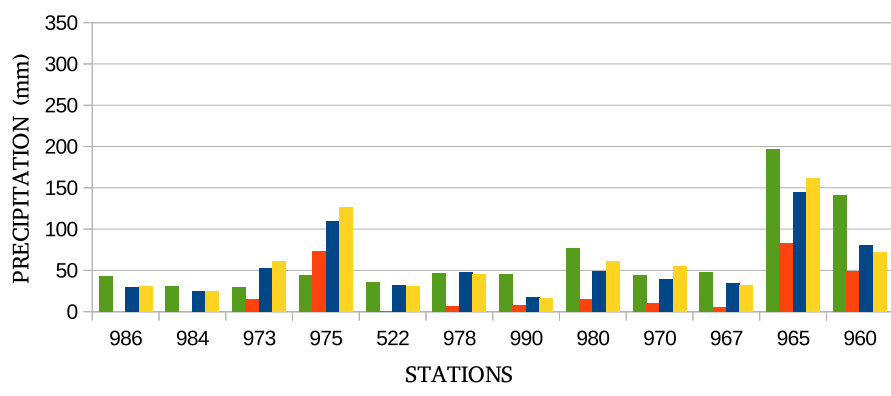

g)

PERIOD 3 - PHASE 2

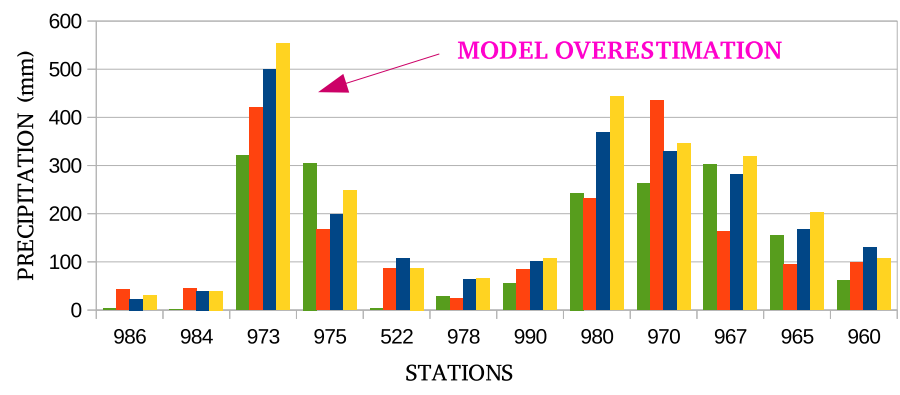

i)

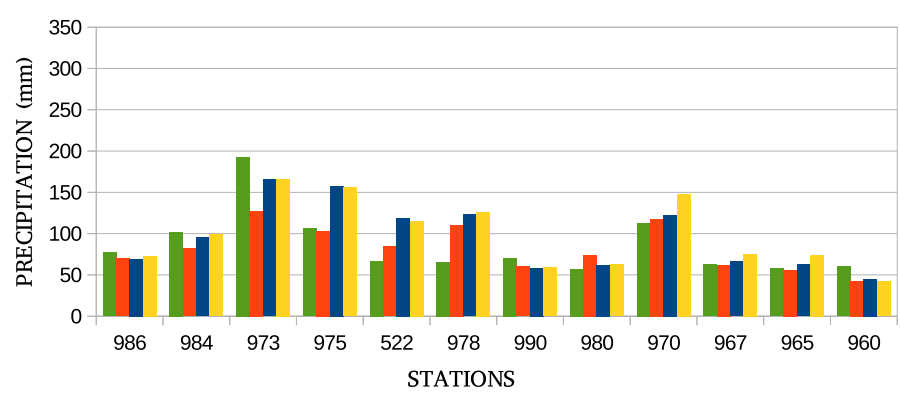

b)

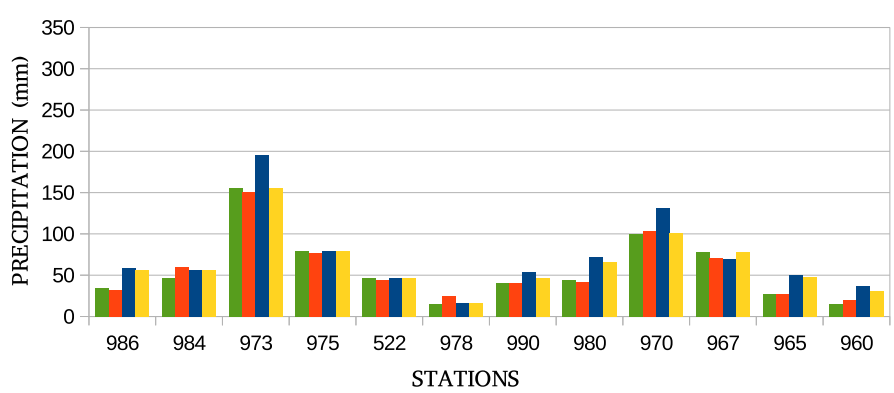

d)

PERIOD 2

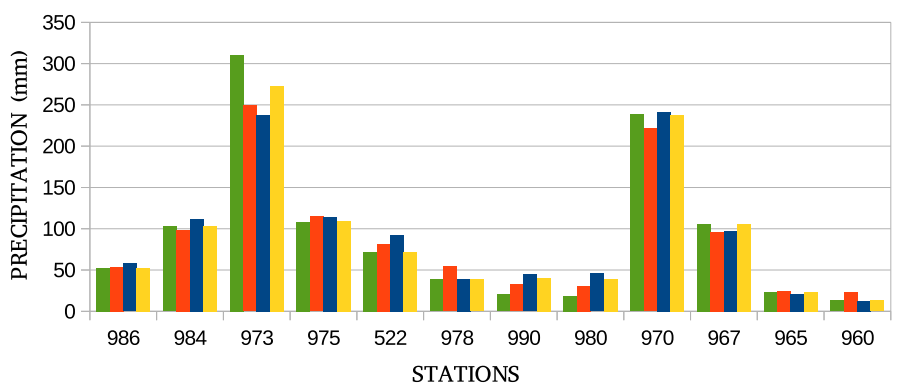

f)

PERIOD 3 - PHASE 1

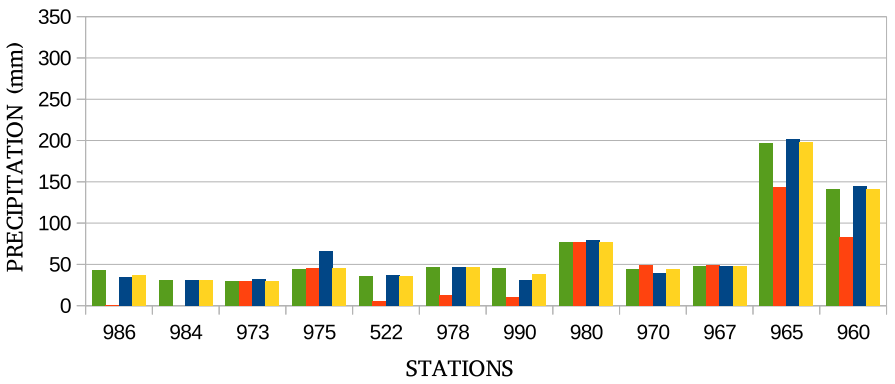

h)

PERIOD 3 - PHASE 2

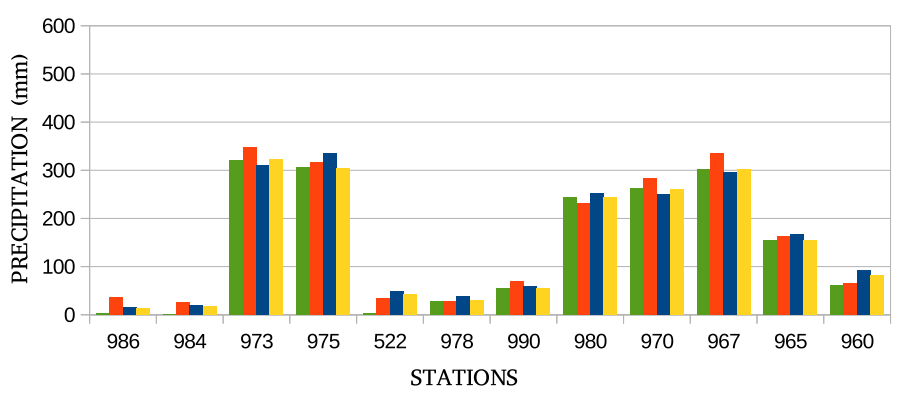

j)

PERIOD 4

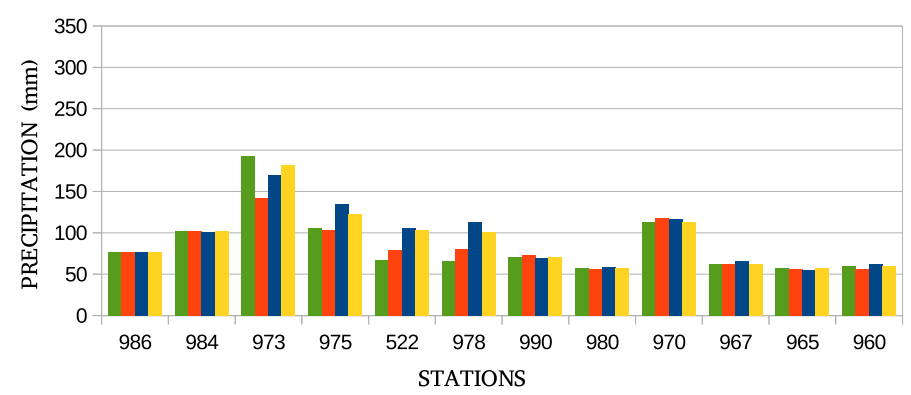


Significant accumulated precipitation

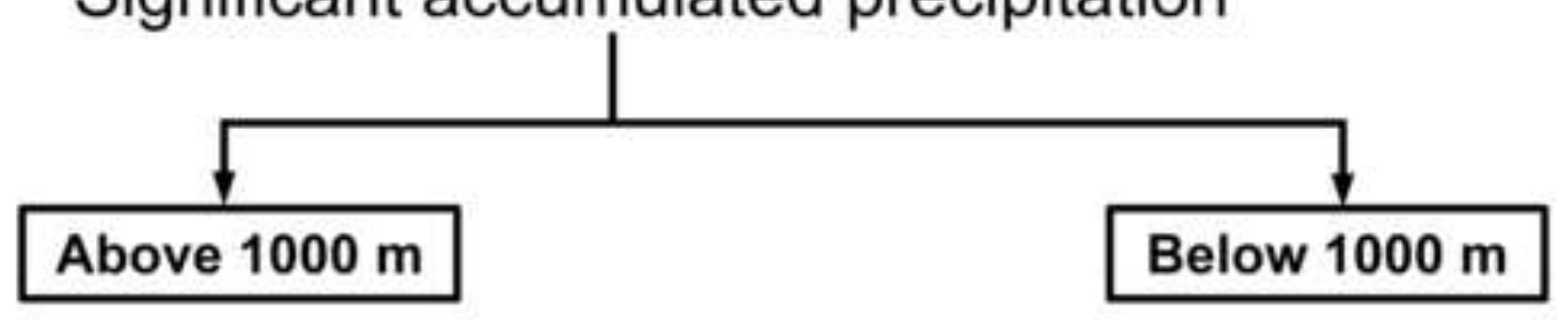

a) Central peaks

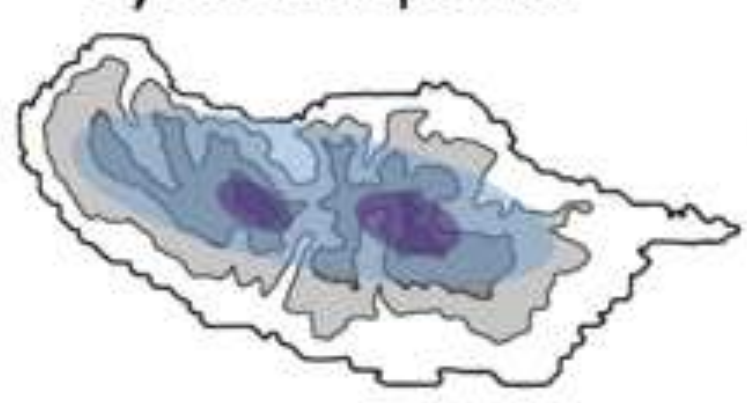

b) Southern slope

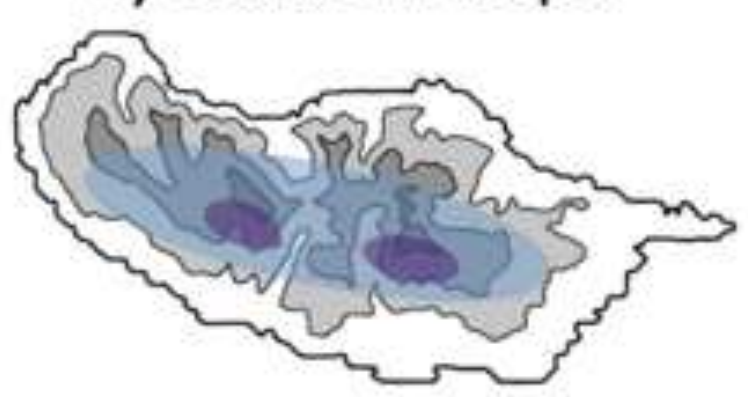

c) Northern slope

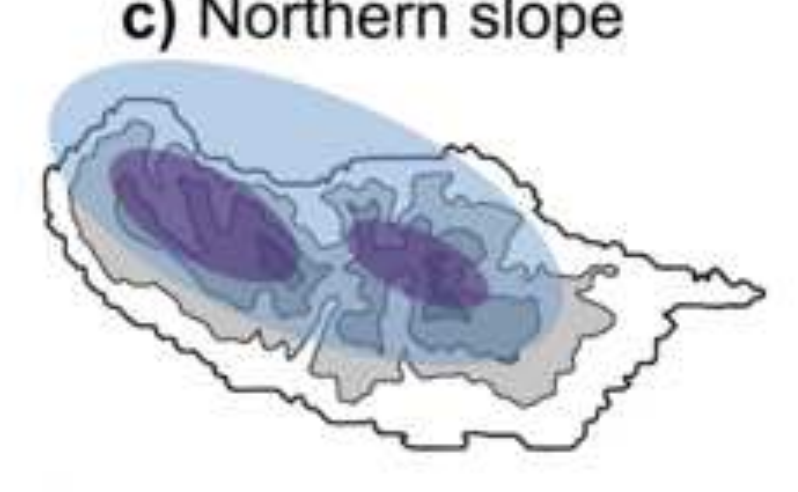

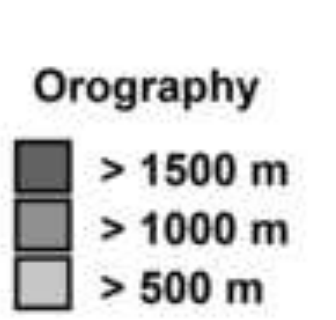

d) Northern slope

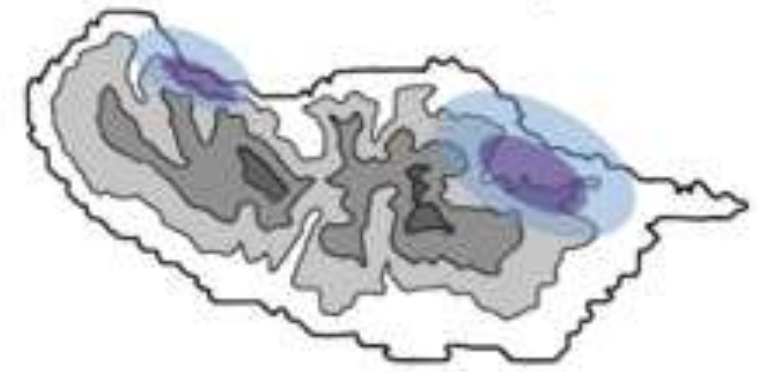

Rainfall

Significant

Maximum 
Table 1. Studied periods and time of model integration for each simulation.

\begin{tabular}{|c|c|c|c|c|c|}
\hline \multicolumn{2}{|c|}{ Study periods } & \multicolumn{3}{c|}{ Numerical experiments } \\
\hline \multirow{2}{*}{ Period } & Start & End & \multicolumn{3}{c|}{ Time of run } \\
\cline { 2 - 6 } & Time/date & Time/date & CTRL & EXPD1 & EXPD2 \\
\hline PERIOD 1 & $18 \mathrm{UTC}-21$ October & $18 \mathrm{UTC}-23$ October & $48 \mathrm{~h}$ & $48 \mathrm{~h}$ & $33 \mathrm{~h}$ \\
\hline PERIOD 2 & $12 \mathrm{UTC}-29$ October & $18 \mathrm{UTC}-30$ October & $30 \mathrm{~h}$ & $30 \mathrm{~h}$ & $24 \mathrm{~h}$ \\
\hline PERIOD 3 & $12 \mathrm{UTC}-04$ November & $18 \mathrm{UTC}-07$ November & $78 \mathrm{~h}$ & $78 \mathrm{~h}$ & $72 \mathrm{~h}$ \\
\hline PERIOD 4 & $18 \mathrm{UTC}-23$ November & $12 \mathrm{UTC}-27$ November & $90 \mathrm{~h}$ & First $42 \mathrm{~h}$ & $24 \mathrm{~h}$ \\
\hline
\end{tabular}


Table 2. Scores for the accumulated precipitation in each period. Pearson correlation (r), Mean Error (ME), Mean Absolute Error (MAE), and Root Mean Squared Error (RMSE) for the nearest grid-point, and for the "best point" in the neighbourhood of the station.

\begin{tabular}{|c|c|c|c|c|c|c|c|c|c|}
\hline \multirow{2}{*}{ Period } & \multirow{2}{*}{ Simulation } & \multicolumn{4}{|c|}{ Nearest grid-point } & \multicolumn{4}{|c|}{ "Best point" in the neighbourhood } \\
\hline & & $\mathrm{r}$ & ME & MAE & RMSE & $\mathrm{r}$ & ME & MAE & RMSE \\
\hline \multirow{3}{*}{1} & CTRL & 0,94 & 26,93 & 28,30 & 38,91 & 0,99 & 0,60 & 4,45 & 5,74 \\
\hline & EXPD1 & 0,86 & 39,13 & 39,21 & 51,64 & 0,96 & 15,29 & 16,73 & 20,95 \\
\hline & EXPD2 & 0,88 & 52,78 & 52,78 & 67,06 & 0,98 & 8,23 & 8,23 & 12,26 \\
\hline \multirow{3}{*}{2} & CTRL & 0,85 & $-5,33$ & 39,68 & 53,26 & 0,99 & $-1,97$ & 13,40 & 20,30 \\
\hline & EXPD1 & 0,93 & $-16,45$ & 33,10 & 43,03 & 0,97 & 1,08 & 15,03 & 24,62 \\
\hline & EXPD2 & 0,90 & $-10,04$ & 30,08 & 41,47 & 0,99 & 0,43 & 6,75 & 13,69 \\
\hline \multirow{3}{*}{$3-\mathrm{PH} 1$} & CTRL & 0,73 & $-42,92$ & 47,75 & 54,99 & 0,89 & $-23,31$ & 24,34 & 32,20 \\
\hline & EXPD1 & 0,77 & $-9,90$ & 24,97 & 33,03 & 0,99 & 0,83 & 5,45 & 8,20 \\
\hline & EXPD2 & 0,71 & $-5,51$ & 26,08 & 35,66 & 1,00 & $-0,98$ & 1,34 & 2,81 \\
\hline \multirow{3}{*}{$3-\mathrm{PH} 2$} & CTRL & 0,77 & 12,92 & 71,52 & 88,80 & 0,99 & 16,47 & 18,27 & 21,35 \\
\hline & EXPD1 & 0,87 & 47,50 & 68,48 & 83,85 & 0,99 & 12,58 & 17,11 & 20,81 \\
\hline & EXPD2 & 0,90 & 67,43 & 76,93 & 100,86 & 1,00 & 7,47 & 7,85 & 13,81 \\
\hline \multirow{3}{*}{4} & CTRL & 0,74 & $-3,41$ & 17,54 & 25,54 & 0,94 & $-2,10$ & 8,05 & 15,96 \\
\hline & EXPD1 & 0,75 & 9,72 & 21,12 & 29,00 & 0,86 & 8,08 & 12,92 & 20,73 \\
\hline & EXPD2 & 0,75 & 13,85 & 24,35 & 30,82 & 0,92 & 6,52 & 8,43 & 15,94 \\
\hline
\end{tabular}

